\title{
Translations and studies of Japanese literature in Vietnam
}

\author{
Nguyen Anh Tuan
}

$凶$ natos2901@gmail.com

This research applies quantitative statistical and qualitative analysis methods to investigate the development of Japanese literary translation and research activities in Vietnam through various periods. Generally, both fields appeared in the first half of the twentieth century, but have developed relatively slowly and only achieved strong growth in terms of the number of publications, along with the main trend of diversification of literary genres to be translated/researched.

Keywords Japanese Literature(日本文学), Vietnam(ベトナム), Translation(翻 訳） 


\section{Introduction}

As the two countries in East Asia, Vietnam and Japan have had a long lasting relationship with numerous cultural and economic exchanges over centuries. However, the reception of Japanese literature in Vietnam has only shaped since the beginning of the 20th century and flourished in recent decades, despite the fact that Japanese literature has been prosperous for thousands of years. This article focuses on studying the situation of this reception on two aspects of translation and research, thus pointing out the main achievements and limitations and suggesting potential directions for Vietnamese translators and researchers in the future.

\section{The evolution of Japanese literary translation in Vietnam}

\subsection{The beginning of Japanese literary translation in Vietnam (pre-1954)}

The first Japanese literary translation in Vietnam is Kajin no Kigu (佳人の奇遇 Stranger Encounters with Beautiful Women) of Tokai Sanshi (東海散士 1852 - 1922), which was translated into Vietnamese by Phan Châu Trinh under the title of Giai nhân kỳ ngộ. Discussing the reason for this translation, Vietnamese researchers carefully examined the content of the original work and Phan's biography, especially his poem entitled Độc giai nhân kỳ ngộ (讀佳人奇遇Reading Kajin no kigu), to come to the conclusion that it was originated from his admiration of patriotic and revolutionary spirit of the work which made up his desire of propagating the model of Japan to awaken Vietnamese people. In other words, he approached the work as a "New Book" (新書) instead of a pure literary work'. For this reason, Phan only translated the first part of the entire work and transposed the prose into poetry (the later part of the work referred to Japanese nationalism, a point of contradictory thoughts of Tokai Sanshi and Liang Qichao - Phan Châu Trinh²; in comparison with prose, poetry was easier for Vietnamese to read and remember, as well as being

\footnotetext{
1 Vĩnh Sính, Về tác phẩm Giai nhân kỳ ngộ diễn ca: Nguồn gốc và ý nghĩa, Việt Nam và Nhật Bản : Giao lưu văn hoá, Vĩnh Sính, Thành phố Hồ Chí Minh : NXB Tổng hợp TPHCM, 2001, pp.465-466.

2 Phan Châu Trinh did not translate from Japanese original work but the Chinese translation of Liang Qichao.
} 
more suitable for propagating revolutionary thoughts ${ }^{3}$ ). On the publication of Giai nhân kỳ ngô, it is noted that this translation was first printed in 1926 but all the copies were confiscated by the French colonial government due to its revolutionary thoughts. It was not until 1958 that Phan's translation was made public in Saigon.

The second Japanese literary work published in Vietnam during this period is Komatsu Kiyoshi's Futsuin e no michi (仏印への途Road to Indochina). And its translated title into Vietnamese was Cuộc tái ngộ (The Reunion). It should be emphasized that Kiyoshi and Futsuin e no michi were special cases among Japanese writers and works introduced in Vietnam for two reasons : Firstly, he had a special love for Vietnam even though he just travelled here in the spring of 1941. It was this love that prompted him to translate Truyện Kiều (傳莬The Tale of Kiều), the masterpiece of Nguyễn $\mathrm{Du}$, into Japanese. Talking about this destiny/fate (緣), Kiyoshi once wrote: "The so-called destiny/fate (奇緣) is often not only one. The one who told me the existence of Kim Vân Kiều is Nguyễn Giang, and the one who translated this work into modern Annnamese or Quốc ngũ̃, then re-translated it into French skillfully is his father who is a famous translator, a great author of modern Annam literature - Nguyễn Văn Vĩnh. Thanks to the valuable guidance of Nguyễn Giang and his father, I had known Kim Vân Kiều even though I did not dare to ask their help. And then, thanks to Kim Vân Kiều, I had understood "the secret of Annam". It is my unexpected happiness"4. Secondly, Futsuin e no michi was not a pure imaginary novel but was based on Komatsu's own experiences with many events related to the country and people of Vietnam. This fact was also confirmed by the author himself in the final section of the work ${ }^{5}$.

In general, with the two works translated into Vietnamese in half a century, Japanese literary translation in Vietnam at this time was extremely limited. It is noteworthy that the selection of Kajin no Kigu and Futsuin e no michi to translate into Vietnamese was more or less linked to the context of contemporary Vietnamese society, rather than the trend of introducing well-known works of Russian and French literature translation in Vietnam in the same period ${ }^{6}$.

\footnotetext{
3 Vĩnh Sính, Về tác phẩm Giai nhân kỳ ngộ diễn ca: Nguồn gốc và ý nghĩa, Việt Nam và Nhật Bản : Giao lưu văn hoá, Vĩnh Sính, Thành phố Hồ Chí Minh : NXB Tổng hợp TPHCM, 2001, p.469.

4 Komatsu Kiyoshi, Bài bạt Kim Vân Kiều, Nghiên cứu Văn học Số 11, 2004, pp.55-61.

5 Komatsu Kiyoshi, Cuộc tái ngộ, Trung Băc tân văn, 1945.

6 In this period, Russian literary translation in Vietnam focused on Lev Tolstoy and Pushkin, while French literary translation focused on Victor Hugo and Honore De Balzac. All are great authors with global influence. Meanwhile, Komatsu Kiyoshi and Tokai Sanshi are not the most prominent authors in modern
} 


\subsection{The formation of Japanese literary translation in Vietnam (1954 - 1975)}

Compared to the first 50 years, the 1954 - 1975 period is noted by the systematic development of Japanese literary translation in Vietnam. The remarkable feature of this period is the distinct differences between socialist North Vietnam and capitalist South Vietnam in the way to select works to translate and the languages of the intermediate translation due to the division of the country.

* In North Vietnam, there were 10 novels, 4 short stories, 1 play and a collection of Japanese fairy tales translated and published, as follows :

Table 1. Japanese literary translation in North Vietnam (1954 - 1975)

\begin{tabular}{|c|c|c|c|c|c|}
\hline $\begin{array}{c}\text { Title of } \\
\text { Vietnamese } \\
\text { translation }\end{array}$ & Author & Translator & $\begin{array}{l}\text { Publishing } \\
\text { information }\end{array}$ & $\begin{array}{l}\text { Original } \\
\text { title }\end{array}$ & $\begin{array}{l}\text { Lang } \\
\text { uage }\end{array}$ \\
\hline $\begin{array}{l}\text { Truyện cổ tích Nhật } \\
\text { Bản }\end{array}$ & N/A & N/A & $\begin{array}{lll}\text { NXB } & \text { Nguyễn } & \mathrm{Du} \\
1957 & & \end{array}$ & $\mathrm{~N} / \mathrm{A}$ & N/A \\
\hline $\begin{array}{l}\text { Khu phố không ánh } \\
\text { mặt trò̀i }\end{array}$ & Sunao Tokunaga & Trương Chính - Hồng Bích Vân & NXB Lao động, 1961 & 太陽のない街 & Chinese \\
\hline Núi đồi yên lăng & Sunao Tokunaga & Trương Chính - Hồng Bích Vân & NXB Văn học, 1962 & \begin{tabular}{|l|l|} 
静かなる山久 \\
\end{tabular} & Chinese \\
\hline Mây gió Hakone & Takakura Teru & Trương Chính - Hồng Bích Vân & NXB Văn học, 1963 & 八コネ用水 & Chinese \\
\hline $\begin{array}{l}\text { Tàu nhà máy cua } \\
\text { hộp }\end{array}$ & Kobayashi Takiji & Mai Hồng & NXB Văn học, 1963 & 蟹工船 & Russian \\
\hline Cánh đồng Bansu & Yuriko Miyamoto & Hồ Dzếnh - Kim Lang & NXB Văn học, 1964 & 播州平野 & Chinese \\
\hline Người cán bộ Đảng & Kobayashi Takiji & Trương Chính - Hồng Dân Hoa & NXB Văn học, 1965 & 党生活者 & Chinese \\
\hline Đoàn kịch Umagoro & Mayama Miho & Trần Công Tá & $\begin{array}{l}\text { Vụ Nghệ thuật sân } \\
\text { khấu, } 1965\end{array}$ & $\mid$ & Chinese \\
\hline Địa chủ vắng mặt & Kobayashi Takiji & Trương Chính - Hồng Dân Hoa & NXB Văn học, 1965 & 不在地主 & Chinese \\
\hline Tế bào xuởng máy & Kobayashi Takiji & Trương Chính - Hồng Dân Hoa & NXB Văn học, 1965 & 工場細胞 & Chinese \\
\hline Cuối thu & Handa Yoshiyuki & Trương Chính - Hồng Dân Hoa & NXB Lao động, 1966 & 鶏騒動 & Chinese \\
\hline Lưa đêm & Nishino Tatsukichi & Trương Chính - Hồng Dân Hoa & NXB Lao động, 1966 & $\mathrm{~N} / \mathrm{A}$ & Chinese \\
\hline $\begin{array}{l}\text { Người lao dộng } \\
\text { Nhật Bản }\end{array}$ & Harukawa Tetsuo & Trương Chính - Hồng Dân Hoa & NXB Lao động, 1966 & 日本労働者 & Chinese \\
\hline Sọi xich trắng & Minakami Tsutomu & Trương Chính - Hồng Dân Hoa & NXB Lao động, 1966 & $\mathrm{~N} / \mathrm{A}$ & Chinese \\
\hline $\begin{array}{l}\text { Đuờng đến nguồn } \\
\text { nuớc }\end{array}$ & Hirotsu Kazuo & Xuân Bích & NXB Lao động, 1974 & 泉へのみち & Russian \\
\hline
\end{tabular}

Japanese literature. 
In addition, there were some poems by Sotokichi Kusaka, Hiroshi Akimura, Noriko Ibaraki, Komori Kyoko, Ikuko Kosakai, Koichi Kihara... translated sporadically in Tuần báo Văn Nghệ (Weekly Magazine of Arts).

It can be seen that except for the collection of Japanese fairy tales originated from ancient masses and not related to political ideology, the other works were classified as proletarian literature which represented the working class and was led by The Japanese Communist Party. Despite the limitation that the selected works were not representative of the entire Japanese literature, this situation can be explained by the context that the authorities of Democratic Republic of Vietnam accepted only the works which were suitable with the view of communism and socialism, regardless of the nationality of the writer. On the other hand, because the socialist state in North Vietnam had only established diplomatic relations with China and the Soviet Union and did not have any official contact with capitalist countries, readers and translators in this region can only access Japanese literary works by Russian and Chinese intermediate translations, instead of the original version. Additionally, in comparison with the translation of other countries' literary works in North Vietnam, Japanese literary translation accounts for only a remarkably small proportion.

* In South Vietnam, the translation of Japanese literary works into Vietnamese was more flourish with 18 novels, 8 short stories, 2 poetry collections, 2 folktale collections and 1 essay collection, as follows :

Table 2. Japanese literary translation in South Vietnam (1954 - 1975)

\begin{tabular}{|c|c|c|c|c|c|}
\hline $\begin{array}{c}\text { Title of } \\
\text { Vietnamese } \\
\text { translation }\end{array}$ & Author & Translator & $\begin{array}{l}\text { Publishing } \\
\text { information }\end{array}$ & $\begin{array}{l}\text { Original } \\
\text { title }\end{array}$ & $\begin{array}{l}\text { Lang } \\
\text { uage }\end{array}$ \\
\hline $\begin{array}{l}\text { Thần thoại Nhật } \\
\text { Bản }\end{array}$ & N/A & Doãn Quốc Sĩ & NXB Sáng tạo, 1972 & N/A & N/A \\
\hline Hoà ca & N/A & Nguyễn Tường Minh & NXB Sông Thao, 1971 & N/A & N/A \\
\hline Luyến ca & N/A & Nguyễn Tường Minh & NXB Sông Thao, 1972 & N/A & N/A \\
\hline $\begin{array}{l}\text { Bên thi hài ngưòi } \\
v o ̛ \text {. }\end{array}$ & $\begin{array}{l}\text { Ogura } \\
\text { Toyofumi }\end{array}$ & Lê Tuyết Thanh & NXB Phổ thông, 1958 & $\begin{array}{l}\text { 絶後の記録 亡 } \\
\text { き妻への手紙 }\end{array}$ & Russian \\
\hline Cô vũ nũ xú Izu & Kawabata Yasunari & Huyền Không & NXB Trình bày, 1969 & 伊豆の踊子 & N/A \\
\hline Em bé Phù Tang & $\begin{array}{l}\text { Ishoco - } \\
\text { Ichiro Hatano }\end{array}$ & Trương Đình Cử & NXB Lá Bối, 1969 & $\begin{array}{l}\text { L'E n f a n t } \\
\text { d'Hiroshima }\end{array}$ & France \\
\hline Năm dài tình yêu & Yoichi Nakagawa & Phạm Quốc Bảo & NXB Hồng Lĩnh, 1969 & 天の夕顔 & N/A \\
\hline Xút tuyết & Kawabata Yasunari & Chu Việt & NXB Trình bày, 1969 & 雪国 & French \\
\hline
\end{tabular}




\begin{tabular}{|c|c|c|c|c|c|}
\hline $\begin{array}{c}\text { Title of } \\
\text { Vietnamese } \\
\text { translation }\end{array}$ & Author & Translator & $\begin{array}{l}\text { Publishing } \\
\text { information }\end{array}$ & $\begin{array}{l}\text { Original } \\
\text { title }\end{array}$ & $\begin{array}{l}\text { Lang } \\
\text { uage }\end{array}$ \\
\hline Kim Các tụ & Mishima Yukio & $\begin{array}{l}\text { Đỗ Khánh Hoan - } \\
\text { Nguyễn Tường Minh }\end{array}$ & NXB An Tiêm, 1970 & 金閣寺 & English \\
\hline Nuôi thù & Oe Kenzaburo & Diễm Châu & NXB Trình bày, 1970 & 飼育 & English \\
\hline Cây đàn Miến Điện & Takeyama Michio & Đỗ Khánh Hoan & NXB Sáng tạo, 1971 & ビルマの竪琴 & English \\
\hline $\begin{array}{l}\text { Chiều hôm lơ } \\
\text { chuyến }\end{array}$ & $\begin{array}{l}\text { Mishima } \\
\text { Yukio }\end{array}$ & $\begin{array}{l}\text { Đỗ Khánh Hoan - } \\
\text { Nguyễn Tường Minh }\end{array}$ & NXB Sông Thao, 1971 & 午後の曳航 & English \\
\hline $\begin{array}{l}\text { Nguời đàn } \quad \text { bà } \\
\text { trong cồn cát }\end{array}$ & $\begin{array}{l}\text { Abe } \\
\text { Kobo }\end{array}$ & Trùng Dương & NXB An Tiêm, 1971 & 砂の女 & English \\
\hline Tiếng sóng & $\begin{array}{l}\text { Mishima } \\
\text { Yukio }\end{array}$ & $\begin{array}{l}\text { Đỗ Khánh Hoan - } \\
\text { Nguyễn Tường Minh }\end{array}$ & NXB Sông Thao, 1971 & 潮騒 & English \\
\hline Ngàn cánh hạc & Kawabata Yasunari & Tuấn Minh & NXB Sống Mới, 1972 & 千羽鶴 & N/A \\
\hline Nỗi lòng & $\begin{array}{l}\text { Natsume } \\
\text { Soseki }\end{array}$ & $\begin{array}{l}\text { Đỗ Khánh Hoan - } \\
\text { Nguyễn Tường Minh }\end{array}$ & NXB Sông Thao, 1972 & こころ & Japanese \\
\hline Một bản tình ca & $\begin{array}{l}\text { Harada } \\
\text { Yasuko }\end{array}$ & Bích Kim & NXB Cảo Thơm, 1973 & 挽歌 & N/A \\
\hline Quy cố huoong & $\begin{array}{l}\text { Osaragi } \\
\text { Jiro }\end{array}$ & Bùi Ngọc Lâm & NXB Đất Sống, 1973 & 帰郷 & N/A \\
\hline Yêu trong mùa thu & $\begin{array}{l}\text { Harada } \\
\text { Yasuko }\end{array}$ & Mặc Đỗ & NXB Đất mới, 1973 & 挽歌 & N/A \\
\hline Sau bũa tiệc & $\begin{array}{l}\text { Mishima } \\
\text { Yukio }\end{array}$ & Tuyết Sinh & NXB Trẻ, 1974 & 宴のあと & English \\
\hline Gót chân giang hồ & $\begin{array}{l}\text { Jippensha } \\
\text { Ikku }\end{array}$ & Trường Sinh & NXB Hải Âu, 1970 & 東海道中膝栗毛 & N/A \\
\hline Góp nhặt cát đá & $\begin{array}{l}\text { Thiền sư } \\
\text { Muju }\end{array}$ & Đỗ Đình Đồng & NXB Lá Bối, 1971 & 沙石集 & N/A \\
\hline Địa ngục môn & $\begin{array}{l}\text { Akutagawa } \\
\text { Ryunosuke }\end{array}$ & Thụ Nhân & NXB Nhị Nùng, 1966 & 地獄変 & English \\
\hline La sinh môn & $\begin{array}{l}\text { Akutagawa } \\
\text { Ryunosuke }\end{array}$ & Thụ Nhân & NXB Nhị Nùng, 1966 & 羅生門 & English \\
\hline Trong hẻm núi & $\begin{array}{l}\text { Akutagawa } \\
\text { Ryunosuke }\end{array}$ & Thụ Nhân & NXB Nhị Nùng, 1966 & 藪の中 & English \\
\hline $\begin{array}{l}\text { Thân phận con } \\
\text { người }\end{array}$ & $\begin{array}{l}\text { Akutagawa } \\
\text { Ryunosuke }\end{array}$ & Diễm Châu & NXB Văn nghệ, 1966 & 河童 & English \\
\hline Nắng mùa hè & Shintaro Ishihara & $\begin{array}{l}\text { Nguyễn Minh Hoàng - } \\
\text { Nhã Điền }\end{array}$ & Văn, Số 57/1966 & 太陽の季節 & N/A \\
\hline Phòng tra tán & Shintaro Ishihara & $\begin{array}{l}\text { Nguyễn Minh Hoàng - } \\
\text { Nhã Điền }\end{array}$ & Văn, Số 57/1966 & スパルタ教育 & N/A \\
\hline Chết giũa mùa hè & Mishima Yukio & Tân Linh & NXB Phù Sa, 1969 & 真夏の死 & N/A \\
\hline Nốt ruồi & Kawabata Yasunari & $\begin{array}{l}\text { Vũ Thư Thanh - Chu } \\
\text { Sương Hạnh }\end{array}$ & Văn, Số 140/1969 & ほくろの手紙 & $\mathrm{N} / \mathrm{A}$ \\
\hline $\begin{array}{l}\text { Đất Phù Tang, cái } \\
\text { dẹp và tôi }\end{array}$ & Kawabata Yasunari & Cao Ngọc Phượng & NXB Lá Bối, 1969 & $\begin{array}{l}\text { 美しい日本の } \\
\text { 私一その序説 }\end{array}$ & N/A \\
\hline
\end{tabular}


The flourish of Japanese literary translation in South Vietnam can be explained by the freedom of foreign cultural and literary reception in this region. It is the fact that literary translation in the two regions in the 1954 - 1975 period had been promoted with hundreds of foreign works. However, by choosing proletarian literature which was only a small part of Japanese literature, North Vietnam were not as successful as South Vietnam in the field of Japanese literary translation, especially in the context of facing political and linguistic barriers on accessing to Japanese works. In contrast, the ideological freedom in South Vietnam had facilitated the reception of foreign culture through many channels including literary translation. Japanese was just one of countries whose literary works were translated and published in this region.

In terms of content, Japanese authors whose works had been translated in South Vietnam belonged to different schools, such as : Neo-Realism (Akutagawa Ryunosuke), Yoyuha (Natsume Soseki), Neo-Sensualism (Kawabata Yasunari)... Among these, the three most prominent ones were Kawabata Yasunari (with 5 works translated in South Vietnam), Akutagawa Ryunosuke (4 works) and Mishima Yukio (5 works). Besides, while North Vietnam focused on modern works, Japanese literary works in South Vietnam included several classical works such as Shasekishu (沙石集Sand and Pebbles), Tokaidochu Hizakurige (東海道中膝栗毛Shank's Mare) and two collections of waka - haiku published under the title of Hoà ca and Luyến ca. However, as same as the situation of Japanese literary translation in North Vietnam, almost Japanese works in South Vietnam were translated through intermediate translations. English and French were the most popular intermediate languages. The reason was probably that there were a few of translators who can translate from Japanese while English and French translators were plentiful in the context that South Vietnam was under the control of France and the US for a long time.

In general, the translation of Japanese literature in Vietnam in both regions in the 1954-1975 period achieved initial results. Despite the differences, they still have some common characteristics : (1) Mainly translating modern authors and works, not paying attention to classical authors and works; (2) Mainly translating prose, not paying attention to poetry and play script; (3) Not translating from Japanese but intermediate languages. 


\subsection{The development of Japanese literary translation in Vietnam (1976 - 2018)}

From 1976 to 1983, Japanese literary translation activities in Vietnam slowed down when no works were translated and published. It can be explained by the socio-economic crisis in Vietnam in the first years after the biggest war in its history. In this situation, the concentration must be economic development and social stability, instead of cultural activities. Since 1984, Japanese literary translation in Vietnam has continued with the release of Endo Shusaku's Watashi ga Suteta Onna (私が棄てた女The Girl I Left Behind) under the title of Nguời đàn bà mà tôi ruồng bỏ. From this time, Japanese literary works are continuously translated and published in Vietnam every year. The hiatus situation which often occurred in the two previous periods has definitely ended. Here are some highlights :

* Firstly, the total volume of works translated and the volume of works by each genre has increased, specifically as follows:

Table 3. The volume of Japanese literary works translated in Vietnam by genre (1901 - 2018)

\begin{tabular}{|c|c|c|c|c|c|c|}
\hline Period & $\begin{array}{c}\text { Novel } \\
\text { (work) }\end{array}$ & $\begin{array}{c}\text { Short } \\
\text { stories } \\
\text { (work) }\end{array}$ & $\begin{array}{c}\text { Poetry } \\
\text { (collection) }\end{array}$ & $\begin{array}{c}\text { Playscript } \\
\text { (work) }\end{array}$ & $\begin{array}{c}\text { Essay } \\
\text { (collection) }\end{array}$ & $\begin{array}{c}\text { Folklore } \\
\text { (collection) }\end{array}$ \\
\hline $1901-1954$ & 1 & 1 & & & & \\
\hline $1954-1975$ & 28 & 12 & 2 & 1 & 1 & 3 \\
\hline $1976-2018$ & 261 & 397 & 9 & 3 & 8 & 21 \\
\hline
\end{tabular}

However, according to the table above, it can be seen that the development level of each genre is not the same, especially there are remarkable differences in absolute value :

- The novels and short stories are still the two most popular genres translated in both absolute volume (233 novels, 385 short stories) and growth rate (novel : 9.3 times, short stories : 33.1 times) in comparison with the 1954 - 1975 period.

+ Novel : During the 1984 - 2005 period, the translation of Japanese novels in Vietnam was spontaneous and unsystematic because the selection of authors and works depends on the subjective assessment of the translator. Since 2006, it has been more systematic when readers can clearly see three main trends: The first is translating works of four well-known modern and contemporary writers, including Murakami Haruki, Banana Yoshimoto, Murakami Ryu and Yamada Amy with the 
boom in the 2006-2010 period (19 of 40 novels translated in Vietnam in this period are the works of the four writers mentioned above); The second is translating noticeable works in the early twentieth century, for example: Dazai Osamu's Ningen Shikkaku (人間失格No Longer Human) under the title of Thất lạc cõi ngườ; Natsume Soseki's Wagahai wa Neko de Aru (吾輩は猫である I am a Cat) under the title of Tôi là con mèo and Kusamakura (草枕The Grass Pillow) under the title of Gối đầu lên cỏ; Tanizaki Junichiro's Man (ÆQuicksand) under the title of Chũ vạn and Chijin no Ai (痴人の愛Naomi) under the title of Tinh khò...; The third is translating light novels to satisfy the needs of young readers which started in 2013 and now account for nearly half of all novels translated in the $2013-2018$ period (74 of 150 works).

Table 4. Translation of light novels in Vietnam (2013 - 2018)

\begin{tabular}{|c|c|c|c|c|c|c|}
\hline Year & 2013 & 2014 & 2015 & 2016 & 2017 & 2018 \\
\hline Volume of light novels translated & 1 & 11 & 8 & 13 & 17 & 14 \\
\hline $\begin{array}{c}\text { Percentage of light novels out of } \\
\text { novels translated }\end{array}$ & $33.3 \%$ & $52.4 \%$ & $47.1 \%$ & $36.1 \%$ & $38.6 \%$ & $48.3 \%$ \\
\hline
\end{tabular}

+ Short stories: The translation of Japanese short stories in Vietnam usually follows two trends: The first is translating a collection of short stories by various authors selected by the editorial board, such as : Truyện ngắn hiện đại Nhật Bản (The Japanese Modern Short Stories, 1996 : 11 authors), Hẹn mùa hoa cúc (菊花の 約The Chrysanthemum Pledge, 2007 : 10 authors), Nàng Tuyết (雪女Snow Woman, 2016)...; The second is translating a collection of short stories by an individual writer, typically Murakami Haruki (6 collection : Đom đóm (螢Firefly, 2006); Ngày đẹp trò̀i để xem kangaroo (カンガルー日和A Perfect Day for Kangaroos, 2006), Sau con động đất (After the Quake, 2006), Bóng ma ơ Lexington (レキシントンの 幽霊Lexington Ghosts, 2007), Nguoòi TV (TVピープルTV People, 2007) and Nhũng ngườ đàn ông không có đàn bà (女のいない男たちMen Without Women, 2014)) and Akutagawa Ryunosuke (3 collections: Tuyển tập truyện ngắn (Selected Short Stories, 1989), Tuyển tập truyện ngắn Akutagawa (Collection of Akutagawa's Short Stories, 2000) and Trinh tiết (貞操Virginity, 2006) and Banana Yoshimoto (1 collection: Thằn lằn (とかげ Lizard, 2008))... In which, the former started earlier and was the main trend before 2004. At this time, Japanese short stories were often translated from French or English intermediate translations. The latter which started 
from 1989 and now has become main trend is marked by the transition from using intermediate translations in the 1989 - 2004 period to using original works since 2005.

- In the 1976 - 2018 period, poetry and folklore literature are also given prominence with nine collections of poetry and 21 collections of folklore literature translated and published. These translations has contributed to the introduction of Japanese poetry which has a long-lasting development history and Japanese folklore literature which is a rich source of traditional cultural meaning. However, the translation of Japanese poetry and folklore literature in Vietnam still has some limitations :

+ Poetry is translated sporadically. The editors often put un-related poems of various authors together into a collection or translate only a tiny part of a big collection, for example : In Hợp tuyển văn học Nhật Bản tù khởi thuỷ đến giũa thế $k y$ XIX (Anthology of Japanese literature from the beginning to the mid-nineteenth century, 2010), Mai Liên mentioned six important collections in Japanese classical poetry (Gosenshu, Shuishu, Goshuishu, Kinyoshu, Shikashu, Senzaishu) but only translated 16 poems in these collection, a extremely small amount of the total number of poems, which made it difficult for readers to get a basic view of Japanese classical waka; Tho haiku Nhật Bản (Japanese haiku, 2004) by Thai Ba Tan selected the works of 36 poets but no one was fully introduced; In Tho cho bốn mùa (Poems for four seasons, 2008), due to the fact that poems was selected according to its "season", the introduction of 92 authors from ancient time to modern time and 103 poems belonging to different genres made it difficult for the readers to study a particular author or poetic genre. Matsuo Basho's Oku no Hosomichi (奥の細道 The Narrow Road to the Deep North) (haiku), Fujiwara Teika's Ogura Hyakunin Isshu (小倉百人一首) (waka) and Myoken Sachiko's Yuki no Hana (雪の花The Snow Flower) (haiku) are only three collections that are fully translated into Vietnamese. Another limitation of Japanese poetry translation in Vietnam is that translators mainly biased haiku while not paying attention to waka and almost ignoring senryu, kanshi and shintaishi. In the future, the full translation of major classical poetry collections (Manyoshu, Kokinshu and Shinkokinshu), Shintaishisho the representative work of shintaishi and the complete work of prominent writers in waka, haiku, senryu, kanshi or shintaishi should be done.

+ In comparison with other genres, most collections of Japanese folklore 
literature are translated from English or French. As Western editors and translators compiling these books had selected from various sources and the process of translating and editing in these countries and Vietnam was not based on a set of united principles. Additionally, the wrong pronunciation of personal names, place names or Japanese terms, even the wrong translation due to the dependence on the intermediate translation or the translator's himself not only make it difficult for readers to understand the works but also can lead to misunderstandings and errors in the research of Japanese folklore scholars, especially those who do not know Japanese. This situation shows that the translation of Japanese folklore in Vietnam needs to be reformed according to the general trend of shifting from indirect translation to direct translation.

- Japanese essay and play script have hardly received the attention of translators. In comparison with the number of 261 novels and 397 short stories, the number of essays translated into Vietnamese is only 8 (including 5 collections fully translated and 3 collections partially translated), while the number of play scripts translated is only 3. For the genre of essay, it can be explained that modern and contemporary Japanese literature does not have a prominent writer specializing in essay while Murasaki Shikibu and Sei Shonagon, the two most famous essay-writers, lived in ancient times whose literature was not given the attention of Vietnamese readers. Among the seven selected essay collections translated in Vietnam, Murakami Haruki's Hashiru Koto ni Tsuite Kataru toki ni Boku no Kataru Koto (走ることについて語るときに僕の語ることWhat I Talk About When I Talk About Running) which was translated under the title of Tôi nói gì khi nói về chạy $b \hat{o}$ is the most well-known one due to the popularity of the author. Murasaki Shikibu's Murasaki Shikibu Nikki (紫式部日記Murasaki Shikibu's Diary) and Sei Shonagon's Makura no Soshi was translated only 6-10 pages as an effort of Mai Liên to introduce Japanese classical literature to the Vietnamese instead of seeking profit. Meanwhile, the play script was not easy to understand and be interested in, Japanese classical Noh and Kabuki plays were almost not performed in Vietnam and did not receive the attention of the audience; therefore, the translation of Japanese play scripts to fulfill the need of readers was not really necessary, publishers and publishing companies also did not would like to explore this genre because of the risk of loss.

- Despite not being shown in the table above, manga has also appeared in 
Vietnam since 1992 with the translation of Doraemon by Kim Dong Publishing House. In spite of being the later genre coming to Vietnam, thanks to manga's own advantage in attracting readers, especially children and teenage, the translation of this genre has quickly developed. Up to now, there are about 700 series of manga translated into Vietnamese. "Shortly after the launch of Doraemon, about 10 manga series was published in Vietnam each year, this number had increased to about 25 series in the latter years. In the recent years, the number of publications in this genre each year has reached 50 series"7. Among the 130 best-selling manga in Japan (over 20 million copies sold), 43 series have been published in Vietnam, for example: One Piece, Dragon Ball, Naruto, Cased Closed, Slam Dunk, Bleach, Doraemon, Touch... In terms of copies, the manga has superiority over other genres. Each volume of manga was 10,000 copies in the 1992 - 2010 period and 5,000 copies in the 2011 - 2018 period (this reduction can be explained by the explosion of online reading website). These numbers are much higher than the number of 1,000 - 2,000 copies of other literary works. In addition, it can not be ignored that ehon (picture book) has been introduced in recent years and quickly developed to meet the reading needs of children.

* Secondly, there have been some variations in terms of the authors' period ${ }^{8}$. In the period of 1984 - 2005, 46 writers whose works were translated into Vietnamese lived in modern times (equivalent to $85 \%$ of the total number of authors introduced), compared with a small number of writers living in classical times (6 authors) and contemporary times (2 authors) $)^{9}$. Since 2006, the second translation of Noruwei no mori (ノルウェイの森Norwegian Wood) under the title of Rùng $N a U y$ has helped Murakami establish a great reputation in Vietnam and opened a new phase for the translation of Japanese contemporary literature. Over the past 10 years, the number of contemporary writers whose works were translated in Vietnam has gradually increased, and has now reached overwhelming proportions of $75 \%$ of the total number of authors introduced between 2006 and 2018 with 126 authors, compared with 37 modern writers and 6 classical writers ${ }^{10}$. It is noteworthy that in addition to the famous writers such as Murakami Haruki, Banana Yoshimoto,

\footnotetext{
7 Nguyễn Huy Thắng, Truyện tranh ở Việt Nam - Thực trạng và triển vọng, Hội thảo nhân 40 năm quan hệ ngoại giao Việt Nam - Nhật Bản, Hà Nội, 2013.

8 Not include the authors of manga and ehon.

9 Not include the authors of poetry, manga and ehon.

10 Not include the authors of poetry, manga and ehon.
} 
Murakami Ryu or Higashino Keigo, with the popularity of the light novel series, young authors under the age of 40 also began to introduce to Vietnamese readers, for example : Kenji Inoue (1980), Kougyoku Izuki (1984) or Kota Nozomi (1989)... This change is partly to catch up with new trend in Japanese literature, but more to satisfy the reading need of Vietnamese youth who would like to relax after working and studying time as well as discovering the life of Japanese youth who has the same age as them, rather than studying the profound meaning in thought or culture in the classical works.

* Thirdly, the translation method of most genres has changed from the indirect translation through intermediate languages (English, French, Russian, Chinese) to the direct translation from the original Japanese works. This trend can be seen obviously from the 2001 - 2005 period when the number of works translated from Japanese was over the number of works translated through intermediate languages for the first time. It is the result of various factors in which these two factors can not be ignored : The first is the development of Japanese translator force due to increasing training size of bachelor program in Japanese Language at universities; The second is the easiness in accessing to the original Japanese works due to the widespread of internet.

Table 5. Percentage of Japanese literary works translated into Vietnamese from Japanese

\begin{tabular}{|c|c|c|c|c|c|c|}
\hline Period & $\begin{array}{c}1984 \\
-1995\end{array}$ & $\begin{array}{c}1996 \\
-2000\end{array}$ & $\begin{array}{c}2001 \\
-2005\end{array}$ & $\begin{array}{c}2006 \\
-2010\end{array}$ & $\begin{array}{c}2010 \\
-2015\end{array}$ & $\begin{array}{c}2016 \\
-2018\end{array}$ \\
\hline $\begin{array}{c}\text { Percentage of Japanese literary } \\
\text { works translated into Vietnamese } \\
\text { from Japanese }\end{array}$ & $1.5 \%$ & $20 \%$ & $54.7 \%$ & $82.4 \%$ & $84.5 \%$ & $96.5 \%$ \\
\hline
\end{tabular}

As for the genres of manga and ehon, $100 \%$ of the works are translated from Japanese. This is due to the simpler access to the original Japanese works of these genres and the simple of language used in the work in comparison with the other genres.

* Finally, donor agencies and publishing companies have played an important role in promoting the translation and introduction of Japanese literature in Vietnam. In the beginning of the $1990 \mathrm{~s}$, in the context of increasing cooperation between

11 Data in the table is only relative because the unit of each category (novel, short story, poetry, play script) is not completely identical. 
Japan and Vietnam, Japanese donors started to implement a number of programs to promote Japanese culture in Vietnam, including literary works. The beginning of this trend was the Toyota Foundation with the funding of the translator Trần Phương Dung to translate Contes du Japon D'autrefois of Yunagita Kumo into Vietnamese in 1992. Subsequently, under the sponsorship of the Toyota Foundation and the Japan Foundation, some other works such as Yuzuru (夕鶴Twilight Crane), Nihon Ryoiki (日本霊異記Ghostly Strange Records from Japan), TUGUMI (TUGUMI Goodbye Tsugumi)... were also in turn introduced in Vietnam, although the number was still small and translating - publishing work was not continuous. The establishment of the Japan Foundation Center for Cultural Exchange in Vietnam in 2008 has partially addressed the situation by providing annual publication funding programs. These grants have enabled many literary works which are valuable but less commercial, such as Konjaku Monogatarishu (今昔物語集Anthology of Tales from the Past), introduced to Vietnamese readers.

Table 6. List of Japanese literary works granted by the Japan Foundation in translation and publication in Vietnam (2006 - 2018)

\begin{tabular}{|c|c|c|c|c|c|}
\hline Vietnamese title & Author & Translator & $\begin{array}{l}\text { Publishing } \\
\text { information }\end{array}$ & $\begin{array}{c}\text { Original } \\
\text { Japanese title }\end{array}$ & Note \\
\hline Vĩnh biệt Tugumi & $\begin{array}{c}\text { Banana } \\
\text { Yoshimoto }\end{array}$ & $\begin{array}{l}\text { Võ Minh Vũ - } \\
\text { Phạm Ngọc Hoa }\end{array}$ & $\begin{array}{l}\text { NXB Đà Nẵng - } \\
\text { Nhã Nam, } 2007\end{array}$ & つぐみ & \\
\hline Amrita & $\begin{array}{c}\text { Banana } \\
\text { Yoshimoto }\end{array}$ & $\begin{array}{c}\text { Trần Quang } \\
\text { Huy }\end{array}$ & $\begin{array}{l}\text { NXB Hội nhà văn } \\
\text { - Nhã Nam, } 2008\end{array}$ & アムリタ & \\
\hline Nhật ký mang thai & Ogawa Yoko & $\begin{array}{l}\text { Lương Việt } \\
\text { Dũng }\end{array}$ & $\begin{array}{l}\text { NXB Văn học - } \\
\text { Nhã Nam, } 2009\end{array}$ & 妊娠カレンダー & \\
\hline $\begin{array}{c}\text { Giáo su và công thúc } \\
\text { toán }\end{array}$ & Ogawa Yoko & $\begin{array}{l}\text { Lương Việt } \\
\text { Dũng }\end{array}$ & $\begin{array}{l}\text { NXB Hội nhà văn } \\
\text { - Nhã Nam, } 2009\end{array}$ & 博士の愛した数式 & \\
\hline Phòng ngủ của Kitahara & Fujino Chiya & \multirow[t]{8}{*}{ Trần Thuỳ Mai } & \multirow{8}{*}{$\begin{array}{l}\text { NXB Thuận Hoá, } \\
2009\end{array}$} & 彼女の部屋 & \multirow{8}{*}{$\begin{array}{l}\text { in the } \\
\text { collection } \\
\text { Bên trong } \\
\text { (Inside } \\
\text { and other } \\
\text { Fiction) }\end{array}$} \\
\hline $\begin{array}{c}\text { Quả trúng không thu } \\
\text { tinh }\end{array}$ & Junko Hasegawa & & & 無精卵 & \\
\hline Bên trong & Rio Shimamoto & & & INSIDE & \\
\hline Bóng cây phong lan & Takagi Nobuko & & & 蘭の影 & \\
\hline Sũa & Tamaki Daido & & & ミルク & \\
\hline Đôi môi non trẻ & Uchida Shungiku & & & 息子の唇 & \\
\hline Ngày hội & Yamada Amy & & & フィエスタ & \\
\hline Giác mo & Yuzuki Muroi & & & PISS & \\
\hline $\begin{array}{c}\text { Vuòn tho trăm huoong } \\
\text { sắc }\end{array}$ & $\begin{array}{c}\text { Fujiwara no } \\
\text { Teika }\end{array}$ & $\begin{array}{c}\text { Trần Thị Chung } \\
\text { Toàn }\end{array}$ & $\begin{array}{l}\text { NXB Thế giới, } \\
2010\end{array}$ & 小倉百人一首 & \\
\hline Người đón tàu & Asada Jiro & Phạm Hữu Lợi & $\begin{array}{l}\text { NXB Văn học - } \\
\text { Nhã Nam, } 2010\end{array}$ & 鉄道員 & \\
\hline
\end{tabular}




\begin{tabular}{|c|c|c|c|c|c|}
\hline Vietnamese title & Author & Translator & $\begin{array}{l}\text { Publishing } \\
\text { information }\end{array}$ & $\begin{array}{c}\text { Original } \\
\text { Japanese title }\end{array}$ & Note \\
\hline Cái lung muốn đá & Wataya Risa & $\begin{array}{l}\text { Nguyễn Thanh } \\
\text { Vân }\end{array}$ & $\begin{array}{l}\text { NXB Hà Nội - } \\
\text { Nhã Nam, } 2010\end{array}$ & 蹴りたい背中 & \\
\hline Mắt trần & Tawada Yoko & $\begin{array}{l}\text { Nguyễn Thu } \\
\text { Hương }\end{array}$ & $\begin{array}{l}\text { NXB Phụ nũ̃, } \\
2011\end{array}$ & 旅をする裸の眼 & \\
\hline Totto-chan bên cưa sổ & $\begin{array}{l}\text { Kuroyanagi } \\
\text { Tetsuko }\end{array}$ & $\begin{array}{l}\text { Trương Thuỳ } \\
\text { Lan }\end{array}$ & $\begin{array}{l}\text { NXB Văn học - } \\
\text { Nhã Nam, } 2011\end{array}$ & $\begin{array}{c}\text { 空ぎわのトットち } \\
\text { やん }\end{array}$ & \\
\hline Tiếng hát người cá & Ono Masatsugu & Lâm Thương & NXB Trẻ, 2012 & 人魚の唄 & \multirow{3}{*}{$\begin{array}{l}\text { in the } \\
\text { collection } \\
\text { Tiếng hát } \\
\text { người cá }\end{array}$} \\
\hline Trôi trên vịnh & Ono Masatsugu & Lâm Thương & NXB Trẻ, 2012 & $\begin{array}{c}\text { にぎやかな湾に背 } \\
\text { 負われた船 }\end{array}$ & \\
\hline $\begin{array}{l}\text { Tù vũng đến vưòn mộc } \\
\text { lan }\end{array}$ & Ono Masatsugu & Lâm Thương & NXB Trẻ, 2012 & $\begin{array}{c}\text { 浦からマグノリア } \\
\text { の庭へ }\end{array}$ & \\
\hline$H \hat{\grave{o}}$ & $\begin{array}{c}\text { Banana } \\
\text { Yoshimoto }\end{array}$ & $\begin{array}{l}\text { Lương Việt } \\
\text { Dũng }\end{array}$ & $\begin{array}{l}\text { NXB Hội nhà văn } \\
\text { - Nhã Nam, } 2012\end{array}$ & みずうみ & \\
\hline $1 Q 84$ & $\begin{array}{c}\text { Haruki } \\
\text { Murakami }\end{array}$ & Lục Hương & $\begin{array}{l}\text { NXB Hội nhà văn } \\
\text { - Nhã Nam, } 2012 \\
\end{array}$ & 1Q84 & \\
\hline Vĩnh biệt, các gangster & $\begin{array}{l}\text { Takahashi } \\
\text { Gen'ichiro }\end{array}$ & Mộc Miên & $\begin{array}{l}\text { NXB Thời đại - } \\
\text { Nhã Nam, } 2013\end{array}$ & $\begin{array}{c}\text { さようなら、ギャ } \\
\text { ングたち }\end{array}$ & \\
\hline $\begin{array}{l}\text { Chuột giã bánh giầy - } \\
\text { Nhũng truyện cổ tích } \\
\text { Nhật Bản hay nhất }\end{array}$ & Toshio Ozawa & $\begin{array}{l}\text { Phan Thị Mỹ } \\
\text { Loan et al }\end{array}$ & $\begin{array}{c}\text { NXB Dân trí - } \\
\text { Alphabooks, } 2014\end{array}$ & ねずみのもちつき & \\
\hline $\begin{array}{l}\text { Con đuoòng này tiếp đến } \\
\text { cửa miệng một ai đó }\end{array}$ & Hachikai Mimi & Lâm Thương & $\begin{array}{l}\text { NXB Hội nhà văn } \\
\text { - Nhã Nam, } 2015\end{array}$ & $\begin{array}{l}\text { Collection of short } \\
\text { stories and Poems }\end{array}$ & \\
\hline Đi cùng ánh sáng & Tobe Keiko & $\begin{array}{l}\text { Nguyễn Song } \\
\text { Tâm Quyên }\end{array}$ & $\begin{array}{l}\text { NXB Kim Đồng, } \\
2015 \\
\end{array}$ & 光とともに . . & Manga \\
\hline Tôi bị bố bắt cóc & Mitsuyo Kakuta & An Nhiên & $\begin{array}{l}\text { NXB Dân trí - } \\
\text { Alphabooks, } 2015\end{array}$ & $\begin{array}{c}\text { キッドナップ. } \\
\text { ツアー }\end{array}$ & \\
\hline $\begin{array}{l}\text { Kim tích vật ngũ tập } \\
\text { (tập thuợng) }\end{array}$ & $*$ & $\begin{array}{l}\text { Nguyễn Thị } \\
\text { Oanh et al }\end{array}$ & $\begin{array}{l}\text { NXB Khoa học } \\
\text { xã hội, } 2016\end{array}$ & 今昔物語集 & $\begin{array}{c}\text { Grants for } \\
\text { translation } \\
\text { only }\end{array}$ \\
\hline $\begin{array}{c}\text { Không chiến Zero rục } \\
\text { lủa }\end{array}$ & Naoki Hyakuta & $\begin{array}{l}\text { Võ Vương Ngọc } \\
\text { Chân }\end{array}$ & $\begin{array}{l}\text { NXB Văn học - } \\
\text { Alphabooks, } 2016\end{array}$ & 永遠のゼロ & \\
\hline $\begin{array}{c}\text { Lời nguyện cầu chín } \\
\text { năm truớc }\end{array}$ & Ono Masatsugu & Dương Thị Hoa & $\begin{array}{l}\text { NXB Văn học - } \\
\text { Nhã Nam, } 2016\end{array}$ & 九年前の祈 & \\
\hline Xú tuyết & $\begin{array}{c}\text { Kawabata } \\
\text { Yasunari }\end{array}$ & Lam Anh & $\begin{array}{l}\text { NXB Hồng Đức - } \\
\text { IPM, } 2018\end{array}$ & 雪国 & \\
\hline Nắp biển & $\begin{array}{c}\text { Banana } \\
\text { Yoshimoto }\end{array}$ & Dương Thị Hoa & $\begin{array}{l}\text { NXB Hội nhà văn } \\
\text { - Nhã Nam, } 2018\end{array}$ & 海のふた & \\
\hline
\end{tabular}

In terms of the number of works translated and published, Vietnamese publishing companies have played a much more important role than donor agencies. After the policy of socialization of the publishing industry was officially put into practice with the Law on Publication in 2004, these companies came into existence 
and quickly entered the translation market with the first wave of the works of Haruki Murakami and Banana Yoshimoto in 2006. From this time, almost $100 \%$ of Japanese literature works introduced in Vietnam has been a result of cooperation and joint ventures between publishing companies and publishing houses. Among these publishing companies, Nhã Nam, Thái Hà, IPM, Phương Nam, AMAK, AZbooks (under brand names such as Mintbooks, Skybooks, Tsuki Light Novel, Shinebooks)... are commonly seen. However, in contrast with the trend of Japanese agencies, Vietnamese publishing companies have always focused on works that are written by best-selling authors or have the potential to satisfy the needs of local young readers. This can lead to negative consequences when the translated works not only do not fully reflect the developments and achievements of Japanese literature, but also lack the educational and human values needed in a literary work. The most obvious evidence of this situation is the rise of the light novel in the past few years.

In general, the Japanese literary translation in the 1984 - 2018 period has developed strongly. This is reflected not only in the number of works introduced to Vietnamese readers, but also in the change of translation method from indirect to direct, the diversification of the genres and the quickness in grasping trends in Japanese contemporary literature.

\section{The evolution of Japanese literary studies in Vietnam}

\subsection{The beginning of Japanese literary studies in Vietnam (pre-1991)}

\subsubsection{The pre-1954 period}

The first study of Japanese literature in Vietnam was Hàn Mặc Tử’s "Japanese literature and the Europeanization Movement" published on the journal Sài Gòn in $1936^{12}$. Despite not being professional researcher, being a poet of "Phong trào Thơ mới” (New Poetry Movement) and realizing that East Asian countries' poetry was in the process of modernization under the influence of Western culture, Hàn would like to study the process of modernizing Japanese poetry with the birth of "shintaishi". However, as he did not know Japanese, his essay was not based on textual research, but merely presented information on the characteristics of the

12 Hàn Mặc Tử, Thi văn Nhật Bản với phong trào Âu hoá, Sài Gòn, 1936. 
process and some typical contemporary poets in Research and Collection on Japanese Literature (George Bonneau) and Japanese Poets today (Liornelle Fiumi), two books of Western researchers. Nevertheless, his comparison of the poetry modernization process in Vietnam and Japan had a suggestive meaning.

After Hàn, Bách Thảo Sương tiên nữ was the second researcher to study Japanese literature in Vietnam with a six-piece of articles entitled "Tang Poetry in Japan" published on the journal Tri Tân in $1942^{13}$. In this study, in addition to the main content of "kanshi" in Japan (called "Tang poetry" by the author), including of the method to read kanshi of the Japanese and the introduction of some kanshi by modern poets such as Emperor Taisho and Nogi Maresuke, Bách Thảo Sương tiên nữ also provided information about the common characteristics of Japanese poetry in general and haiku in particular. The remarkable point of these articles is the fact that the author used some kanshi to analyze and presented her perspectives instead of re-telling the information in Western books.

In relation to the Japanese literary translation of this period, it can be seen that the above two studies are completely unrelated to the works translated into Vietnamese but carried out for the personal purpose of the researchers. It can be explained by the fact that the number of works translated into Vietnamese was very small and the translations were not widespread (Giai nhân kỳ ngộ was confiscated as soon as being published, Cuộc tái ngộ was only published in the North and the Central of Vietnam) while there were a few of Vietnamese understanding Japanese (the content of the general educational program at this time only included Vietnamese and French). On the other hand, although the two studies mentioned above could not lay the foundation for the field of Japanese literary studies in Vietnam, they reflected partially the interest of Vietnamese intellectuals in Japanese literature. They also provided an overview of modern Japanese poetry with the parallelism of traditional poetic forms such as kanshi, haiku, waka and shintaishi.

\subsubsection{The 1954 - 1975 period}

In this period when Vietnam was divided into two regions, due to the translation of Japanese literature in North Vietnam and South Vietnam had different developments, the development of the field of Japanese literary also followed two heterogeneous trends :

13 Bách Thảo Sương tiên nữ, Thơ Đường ở Nhật Bản, Tri Tân, 1942. 
* In North Vietnam, although some short stories, novels and poems of Japanese proletarian literature was translated into Vietnamese, studies of Japanese literature was still limited when there was only one book review entitled "Irrigation Water of Hakone, a novel by Takakura Teruo"14 and some introductory paragraphs on the authors and their works in the translations. It can be explained by placing translation and research on Japanese literature in relation to translation and research on other countries' literature in North Vietnam. In this period, translation and research on world literature in North Vietnam focused on the literature of socialist countries such as the Soviet Union, China and even the East European socialist countries. In contrast, the literature of the capitalist countries was not paid much attention due to the influence of political ideology. Therefore, it can be understood that translators and scholars in North Vietnam did not focus on the literature of Japan - a capitalist country, where proletarian literature was not the mainstream.

* In South Vietnam, due to the certain freedom of political ideology, literary translation activities were more promoted with numerous famous works translated into Vietnamese. They provided a rich source of documents for scholars to study Japanese literature. As a result, the number of Japanese literary studies in South Vietnam was also higher than in North Vietnam. In addition to the introductory paragraphs in the translations, there were 10 independent articles on Japanese literature in Tạp chi Văn học (Journal of Literature) :

Table 7. Japanese literary studies in South Vietnam (1954-1975)

\begin{tabular}{|c|c|c|}
\hline Title & Author & Publishing information \\
\hline Bài thơ con cóc bất hủ trong nền văn học Nhật & $\begin{array}{l}\text { Nguyễn } \\
\text { Giang }\end{array}$ & Văn học (miền nam), Số 90 - 1969 \\
\hline Đọc văn Yasunari Kawabata & Vũ Thư Thanh & Văn học (miền nam), Số 90 - 1969 \\
\hline $\begin{array}{l}\text { Kawabata - nhà văn Nhật Bản đầu tiên được } \\
\text { giải Nobel văn học }\end{array}$ & Mai Chương Đức & Văn học (miền nam), Số $144-1972$ \\
\hline Tiểu thuyết Nhật Bản & Mai Chương Đức & Văn học (miền nam), Số 90 - 1969 \\
\hline Vài nét về nhà thơ Nhật Bản Ishikawa Takuboku & Vĩnh Sính & Văn học (miền nam), số 90 - 1969 \\
\hline Vài nét về thơ Haiku với thi bá Matsuo Basho & Nguyễn Văn Tần & Văn học (miền nam), Số 90 - 1969 \\
\hline Yasunari Kawabata - cuộc đời và sự nghiệp & Vũ Thư Thanh & Văn học (miền nam), Số 90 - 1969 \\
\hline Yasunari Kawabata dưới nhãn quan phương Tây & Chu Sỹ Hạnh & Văn học (miền nam), Số 90 - 1969 \\
\hline Yasunari Kawabata giải Nobel văn chương 1968 & Đào Hữu Dũng & Văn học (miền nam), Số 90 - 1969 \\
\hline Yếu tố Eros trong truyền thống văn học Nhật Bản & Uyên Minh & Văn học (miền nam), Số 90 - 1969 \\
\hline
\end{tabular}

14 Nguyễn Năm, Mây gió Hakone, tiểu thuyết của Takakura Teruo, Nghiên cứu Văn học, Số 2, 1964, pp.83-86. 
Among them, while Vĩnh Sính, Đào Hữu Dũng, Vũ Thư Thanh and Nguyễn Văn Tần only introduced the life and career of Ishikawa Takuboku, Kawabata Yasunari and Matsuo Basho, the articles of Uyên Minh, Mai Chương Đức and Nguyễn Bằng Giang dealt with specific issues, such as : Eros which was one of Japanese literary traditions ("Eros in Japanese literary tradition"15); the development of Japanese novels from Heian period to modern times ("Japanese novels",16); the characteristics of the reception of Japanese poetry in Vietnam, as well as the Japanese poetic concept by analyzing Matsuo Basho's poetry (“An immortal poem of Basho in Japanese literature"17). However, these articles were not closely associated with translation activities as their contents were often based on foreign research, instead of using original works or translations to study.

* Besides, in spite of not being the researches conducted by Vietnamese scholars, some works introduced in both North Vietnam and South Vietnam by translating foreign scholars' researches also provided valuable information about the outline of Japanese modern literature, such as the article entitled "Situation of Japanese modern literature"18 by Sei Kubota and the 18th chapter entitled "Japanese literature" in World Modern Literature, a book written by R. M. Alberes, Roger Bastile, Rene Sieffert ${ }^{19}$.

\subsubsection{The 1976 - 1990 period}

In the period of 1976-1990, Japanese literary research activity in Vietnam seemed frozen when only two articles studying haiku were published : "Autumn and Japanese Poetry"20 (Nguyễn Vỹ, 1982) and "Studying Japanese haiku"21 (Nhật Chiêu, 1986). It can be explained by Vietnam's difficult economic situation after the war, which made the activities of cultural exchanges and world literary studies in general and Japanese literary studies in particular face many obstacles. It was reflected by the stagnation of Japanese literary translation in the period of 1976 1983. However, while the translation activity had been recovered since 1984,

\footnotetext{
15 Uyên Minh, Yếu tố Eros trong truyền thống văn học Nhật Bản, Văn học (miền nam), Số 90, 1969. 16 Mai Chương Đức, Tiểu thuyết Nhật Bản, Văn học (miền nam), Số 90, 1969.

17 Nguyễn Bằng Giang, Bài thơ con cóc bất hủ trong nền văn học Nhật, Văn học (miền nam), Số 90, 1969.

18 Sei Kubota, Tình hình văn học hiện đại Nhật Bản, Nghiên cứu Văn học, Số 6, 1965, pp.82-89.

19 R. M. Alberes, Roger Bastile, Rene Sieffert, Văn học thế giới hiện đại, Bửu Ý dịch, Sài Gòn : NXB An Tiêm, 1973.

20 Nguyễn Vỹ, Thu và thơ Nhật Bản, Phổ thông, Số 43, 1982.

21 Nhật Chiêu, Tìm hiểu thơ haiku Nhật Bản, Sông Hương, Số 21, 1986.
} 
research activity had not been thrived yet because of the limited availability of translation works to common readers in general and researchers in particular, as well as the time gap between translation activity and research activity in the context that the number of scholars who could study Japanese original works was limited.

Generally, in comparison with the starting point of Japanese literary translation, the starting point of Japanese literary studies in Vietnam was not too late, but the development of this field in the 1936 - 1990 period had been greatly slow. Compared to the number of translations, the number of studies was small. On the other hand, most of these studies were only the introduction of genres, authors or works, and there was no clear approach or research problem.

3.2 The foundation of Japanese literary studies in Vietnam (1991 - 2005)

As mentioned above, Japanese literary research activity in the period of 1936-1990 was only at the beginning when the number of researches was small, the publishing was not continuous (even interrupted for years) and the content of articles was mainly introductory. It was not until the 1990s that the study of Japanese literature in Vietnam was really shaped. This situation was expressed in some aspects below.

\subsubsection{The advent of general studies of Japanese literary history}

While the Japanese literary studies by Vietnamese scholars in the period of 1936 - 1990 were only journal articles, some general studies of Japanese literary history were published, which provided common readers in general and researchers in particular a comprehensive overview of Japanese literary history.

* First of all, it can not be ignored that A Journey on Japanese Literature (Hũu Ngọc, 1992) ${ }^{22}$ as the first Japanese literary studies book in Vietnam. The author chose the two-tiered approach : the first part presented the general characteristics of Japanese literature in different periods (for example: Women's literature in Heian period, warrior class's literature in Kamakura period; townspeople's literature in Edo period); the second part studied specific authors and

22 Hữu Ngọc, Dạo chơi vườn văn Nhật Bản, Hà Nội : NXB Giáo dục, 1992 
works. This approach made the book have both a general width and a depth with specific problems. However, Hữu Ngọc's critics were not based on a clear theoretical framework but mainly depended on his own subjective aesthetic sense. Therefore, the book was not only lack of a scientific style but also in confusion.

* Compared to the characteristic of a "journey" in Hữu Ngọc's book, Japanese literature from its beginning to 1868 (Nhật Chiêu, 1998) ${ }^{23}$ was more pedagogical because it was compiled based on author's lecture series of Japanese literature at Vietnam National University Hochiminh City. Using a historical approach, Nhật Chiêu outlined the history of Japanese literature from the beginning to 1868 into four major periods whose feature was highlighted in the chapter title : Nara - the dawn of Japanese literature; Heian - the era of beauty; medieval - the era of war; Edo - the literature of ukiyo. In each chapter, the author chose some important writers and works which represented 3 major genres of Japanese literature (including prose, poetry and play script) to study thoroughly.

Table 8. Some works representing for genre and period in Japanese literature from its beginning to 1868

\begin{tabular}{|c|c|c|c|}
\hline & Prose & Poetry & Play script \\
\hline Nara & Kojiki, Nihonshoki & Manyoshu & \\
\hline Heian & Genji, Makura no Soshi & Kokinshu & \\
\hline Medieval & Heike, Hojoki & Sankashu, Kyounshu & Zeami \\
\hline Edo & Saikaku & Basho, Buson, Issa & Chikamatsu \\
\hline
\end{tabular}

The most outstanding feature of this work, which is also the characteristic of Nhật Chiêu's research style, is that the author successfully applied the concept of "trying to understand and empathize with the study subject", instead of "consider the study subject through inherent lens" ${ }^{24}$. It made the work elaborate but not dry like other studies of literary history. In addition, as a college textbook, Japanese literature from its beginning to 1868 contributed to fostering fundamental knowledge of Japanese literature for hundreds of students studying Japanese literature in particular and literature in general throughout Vietnam, which was a precondition for the selection of specific issues in later researches.

* In addition to the above two books, the overview of Japanese literary history

23 Nhật Chiêu, Văn học Nhật Bản tử khởi thuỷ đến 1868, Hà Nội : NXB Giáo dục, 1998.

24 Nguyễn Thị Thanh Xuân, Văn học Nhật Bản tại Việt Nam, Thành phố Hồ Chí Minh : NXB Đại học Quốc gia Thành phố Hồ Chí Minh, 2008, p.106. 
was briefly featured in several books on Japanese culture or Asian literature as a chapter, such as : Nhật Bản trong chiếc guoong soi (Japan in the Mirror), Đại cuơng văn hoá phưong Đông (Introduction to Oriental Culture), Câu chuyện văn chuoong phuơng Đông (The Story of Oriental Literature), Nhật Bản - đất nuoóc, con ngưòi và văn học (Japan - Country, People and Literature)...

\subsubsection{The regular appearance of articles in academic journals}

Although the publication of Japanese literary research papers began in 1936, this activity had been spontaneous and sparse for a long time. In many years, no article studying Japanese literature was published. This situation only ended in 1991 when studies of Japanese literature have appeared continuously and regularly in Vietnam's academic journals :

Table 9. Number of Japanese literary studies in Vietnam's academic journals (1991 - 2005)

\begin{tabular}{|c|c|c|c|c|c|c|c|c|c|c|c|c|c|c|c|}
\hline Year & 1991 & 1992 & 1993 & 1994 & 1995 & 1996 & 1997 & 1998 & 1999 & 2000 & 2001 & 2002 & 2003 & 2004 & 2005 \\
\hline $\begin{array}{c}\text { Number } \\
\text { of articles }\end{array}$ & 1 & 4 & 1 & 3 & 3 & 1 & 5 & 5 & 7 & 4 & 4 & 4 & 6 & 6 & 12 \\
\hline
\end{tabular}

In total, 66 articles were published in this period. This number was four times higher than the total of 16 articles in the previous 44 years (1936 - 1990).

One noteworthy point is the appearance of Tạp chi Nghiên cúu Nhật Bản (Vietnam Review of Japanese Studies) in 1995 as the first academic journal of Japanese Studies in Vietnam ${ }^{25}$. In the third issue, this journal published its first article about Japanese literature entitled "Matsuo Basho - the Great Poet of Haiku" (Nguyễn Tuấn Khanh, 1995) ${ }^{26}$. From this time, Japanese literary researchers have had a suitable forum for publishing their works ${ }^{27}$. Continuing the Vietnam Review of Japanese Studies, the Literature Studies began to pay attention to Japanese literature which had been ignored for many years and published some articles by Trần Hải

25 The Center of Japanese Studies was established in the context that area studies has increasingly developed on a world scale and attracted the attention of Vietnamese scholars in the early 1990s. This context promoted the establishment of institutions of area studies (Chinese Studies, Japanese Studies, American Studies, European Studies...) under the National Center for Social Sciences and Humanities and faculties of area studies (Oriental Studies, International Studies...) under universities.

26 Nguyễn Tuấn Khanh, Matsuo Basho, nhà thơ lớn của thể thơ haiku, Nghiên cứu Nhật Bản, Số 3, 1995, pp.48-51.

27 To date, Tạp chí Nghiên cứu Đông Bắc Á (Vietnam Review of Northeast Asian Studies) - the new name of the Tạp chí Nghiên cứu Nhật Bản (Vietnam Review of Japanese Studies) is still the leading journal in terms of the number of articles on Japanese literature published in Vietnam (80 articles). 
Yến, Nhật Chiêu, and Đoàn Lê Giang in the period of 1996 - 1998. Thanks to the advantage of expertise (Japanese Studies and literature), these two academic journals soon attracted the attention and interest of Vietnamese scholars, therefore became the two most important forum for Japanese literary studies in the country. In total, from 1991 to 2005, these two journals published 36 papers on Japanese literature, accounting for $53.7 \%$ of the total journal articles in the field.

\subsubsection{The trend of introducing authors, works and selecting general issues}

In the context that Japanese literary studies in Vietnam in previous periods were not only small in quantity but also superficial in content, researches going into the general issues of the entire Japanese literature or a genre, a certain literary period to help scholars gain an overview of Japanese literature were definitely necessary. Therefore, it can be explained easily why Vietnamese researchers followed this research trend. According to our statistics, there were 43 publications studying general issues of Japanese literature in the period of 1991 - 2005, accounting for $50 \%$ of the Japanese literary studies in Vietnam in this period. Here is some typical ones : "Novel written by Chinese character in Japan" (Trần Nghĩa, $1993)^{28}$, "Japanese modern literature from the Meiji era until now" (Nguyễn Tuấn Khanh, 1998) 29; "Some Characteristics of Japanese Literature" (Trần Hải Yến, 1999)30; "About Japanese manga" (Hạ Thị Lan Phi, 2004) ${ }^{31} \ldots$ It should be noted that these articles mainly based on previous researches by foreign scholars instead of directly studying a large amount of the original Japanese works to make a general statement. Therefore, these trend-based studies were often lacking in novelty and originality. However, they still had a certain value in contributing to solve the shortage of background knowledge on Japanese literature of Vietnamese researchers and creating a prerequisite for them to go into specific authors and works in later researches.

In correlation with other periods, the proportion of the studies of specific authors and works in the period of 1991-2005 was somewhat lower, but the number of 43 works (equivalent to $50 \%$ of Japanese literary studies in Vietnam in this

28 Trần Nghĩa, Tiểu thuyết chữ Hán của Nhật Bản, Hán Nôm, Số 4, 1993.

29 Nguyễn Tuấn Khanh, Văn học Nhật Bản hiện đại từ thời Minh Trị đến nay, Văn học Nhật Bản, Hà Nội : Viện Thông tin Khoa học Xã hội, 1998, pp.91-107.

30 Trần Hải Yến, Một số nét đặc trưng của văn học Nhật Bản, Nghiên cứu Nhật Bản, Số 4, 1999, pp.31-38.

31 Hạ Thị Lan Phi, Vài nét về manga Nhật Bản, Nghiên cứu Đông Bắc A, Số 6, 2004, pp.32-41. 
period) also affirmed their undeniable contribution to the field of Japanese literary studies in Vietnam. Through these studies, a lot of prominent figures in Japanese literature were introduced to Vietnamese scholars, typically Kawabata Yasunari in the novel genre and Matsuo Basho in the haiku genre. However, the authors mainly introduced the life and career of the writers and the content of their works while new approaches and methodologies in literary studies were not used. Therefore, they could not be highly evaluated in terms of originality and novelty.

\subsubsection{The role of translating researches of foreign authors}

An important feature of Japanese literary studies in Vietnam during the 1991-2005 period was the appearance of a series of articles by foreign scholars. According to my statistics, there were a total of 1 monograph and 18 articles by Japanese literary experts from Japan, UK, US and Russia selected and translated into Vietnamese by the research agencies. In correlation with the number of studies conducted by Vietnamese scholars during this period, the amount of foreign scholarly work accounted for a significant ratio (21\%). In my opinion, translating selected studies of foreign scholars was the right choice in the context that Japanese literary studies in Vietnam was primitive due to limitations in force, finance, document and methodology. In order to solve these problems, it was necessary to translate some typical literary studies of foreign authors to provide Vietnamese researchers a comprehensive view of Japanese literature, which could establish the basis for the selection of research problems in the later period. In addition, it can not be ignored the existence of in-depth papers on specific issues which were useful for Vietnamese researchers to learn latest methodologies and documents in the field of Japanese literature, for example : "Zen in Japanese Haiku" (Tatiana P. Grigorieva, 1992) ${ }^{32}$ applied cultural approach to discover the meaning of Zen in Japanese haiku; "Two Ladies Kieu in Vietnam and Japan" (Kawaguchi Kenichi, 1998) ${ }^{33}$ provided information on the existence of Tsuzoku Kingyoden (通俗金趣伝 Vernacular Translation of the Story of Gentleman Jin and Two Sisters Yun and Qiao) in Japan for the first time, and set up a comparison between the reception of Qingxin Cairen (青心才人)'s Jinyunqiao Zhuan (金趣雲伝Story of Gentleman Jin and Two Sisters Yun and Qiao) in Japan and Vietnam.

32 Tatiana P. Grigorieva, Thiền trong thơ Haiku Nhật Bản, Nghiên cứu Văn học, Số 4, 1999, pp.60-64.

33 Kawaguchi Kenichi, Hai nàng Kiều Việt Nam và Nhật Bản, Kỷ yếu Hội thảo quốc tế Việt Nam học lần I, Hà Nội : NXB Đại học Quốc gia Hà Nội, 1998, pp.113-116. 
In short, Japanese literary research in Vietnam in this period had positive changes compared to the previous period and contributed to the foundation for the later development in many aspects, especially background knowledge of Japanese literature and research methodologies. In addition, through the increase in the number of studies, it can be seen that Vietnamese scholars have considered Japanese literature as a potential research field to study thoroughly.

\subsection{The development of Japanese literary studies in Vietnam (2006 - 2018)}

In the context that Japanese literary translation was promoted continuously with hundreds of works published, Japanese literature was increasingly receiving the attention of common readers in general and scholars in particular, the field of literary studies was provided with new approaches and methodologies, Japanese literary research activities in Vietnam in the period of 2006 - 2018 have progressed remarkably in comparison with the previous period. This development is reflected in several aspects :

\subsubsection{The dramatic increase in the number of studies}

In the period of 2006 - 2018, the number of studies of Japanese literature in all four categories (monograph, journal article, article in proceedings and collections and $\mathrm{PhD} / \mathrm{MA}$ thesis) increased sharply compared to the 1991-2005 period.

Table 10. Japanese literary studies in Vietnam by publication format $(1991-2018)$

\begin{tabular}{|c|c|c|c|c|}
\hline & Monograph & Journal article & $\begin{array}{c}\text { Article in collections } \\
\text { and proceedings }\end{array}$ & MA and PhD thesis \\
\hline $1991-2005$ & 4 & 66 & 15 & 1 \\
\hline $2006-2018$ & 8 & 204 & 115 & 52 \\
\hline
\end{tabular}

* Monograph : In correlation with other publication formats, the number of monographs increased not so much in absolute terms, but the works published in this format have made an obvious change in research subject and scope. In particular, while three-quarters of the monographs published during the period of 1991-2005 were general studies, 50\% of the monographs published from 2006 to 
2018 studied specific issues (authors and works), for example : Japanese Culture and Kawabata Yasunari studied the meaning of Japanese traditional culture in Kawabata Yasunari's works ${ }^{34} ; A$ study of type and motif of Vietnamese and Japanese folktales from comparative perspective studied a specific aspect of Japanese folktales and put it in the comparison with Vietnamese folktales ${ }^{35}$; Some outstanding writers in Japanese modern literature not only introduced the life and career of 10 Japanese famous writers (Mori Ogai, Natsume Soseki, Tanizaki Junichiro...) but also studied thoroughly the characteristics in writing style of each authors $^{36}$; Comparison of Love-Story Novels in some Middle-Age Oriental Countries focused on studying a unique sub-genre of East Asian classical novel in general and Japanese classical novel in particular through some typical works ${ }^{37}$.

* $\mathrm{PhD} / \mathrm{MA}$ thesis : While there was only 1 thesis studying Japanese literature entiled Giai nhân kỳ ngộ diên ca in the patriotic novels in the early 20th century (Trần Hải Yến, 1998) ${ }^{38}$ in the period of 1991-2005, the number of theses in the 2006 - 2018 period has increased to 52. This number not only reflects the interest of Japanese literature of undergraduate and graduate students, but also confirms that the introduction of Japanese literature in universities has yielded certain results in training young researchers in this field. Additionally, the content of theses shows that the students mainly focus on solving a specific author or work instead of choosing general issues. This is an appropriate choice for the level and training requirements for students.

* Journal articles : In the 2006 - 2018 period, the number of journal articles studying Japanese literature continues to increase to 204 articles which is three times more than the 1991-2005 period. It is noted that the source of journals are more diversified and specialized. Specifically, in the previous period, although articles published in Literature Studies and Vietnam Review of Northeast Asian Studies (the new title of Vietnam Review of Japanese Studies) accounted for 54.5\% of Japanese literary studies in Vietnam, there were many articles published in

34 Đào Thị Thu Hằng, Văn hoá Nhật Bản và Kawabata Yasunari, Hà Nội : NXB Giáo dục, 2007.

35 Nguyễn Thị Nguyệt, Khảo sát và so sánh một số típ truyện và môtip truyện kể dân gian Việt Nam Nhật Bản, Hà Nội : NXB Đại học Quốc gia, 2010.

36 Nguyễn Tuấn Khanh, Những cây bút kiệt xuất trong văn học Nhật Bản hiện đại, Hà Nội : NXB Khoa học Xã hội, 2011.

37 Hà Thanh Vân, So sánh loại tiểu thuyết "tài tử giai nhân" ở một số nước phương Đông thời kỳ trung đại, Hà Nội : NXB Khoa học Xã hội, 2010.

38 Trần Hải Yến, Giai nhân kỳ ngộ diễn ca trong dòng văn học duy tân yêu nước đầu thế kỷ XX, Luận án tiến sĩ, Hà Nội : Viện Văn học, 1998. 
journals which was published to serve common readers rather than scholars and not suitable for publishing in-depth studies in this field, such as Kiến thức ngày nay (Today's Knowledge), Văn nghệ trẻ (Youth's Art)... On the contrary, in the period of 2006 - 2018, in addition to the influential national journal such as Tap chi Nghiên cứu Đông Bắc Á (Vietnam Review of Northeast Asian Studies, 61 articles), Tạp chí Nghiên cứu Văn học (Literature Studies, 48 articles) and Tạp chí Văn hoá - Nghệ thuật (Arts and Culture, 16 articles), many academic journals of major universities in Vietnam have also published a lot of articles on Japanese literature, such as Tap chi Khoa học Đại học Su phạm Hà Nội (Journal of Science of Hanoi University of Education, 14 articles), Tạp chi Khoa học Đại học Su phạm Thành phố Hồ Chí Minh (Journal of Science of Ho Chi Minh City University of Pedagogy, 7 articles), Tạp chi Khoa học Đại học Đà Nã̃ng (Journal of Science of University of Danang, 4 articles)...

* Articles in proceedings and collections : During the period of 1991-2005, although there were some articles on Japanese literature appeared in a number of conferences, such as Conference for Female Scientist (Vietnam National University Hanoi, 1999 - 2000), Conference for Young Researchers in Philology (Hanoi National University of Education, 2004)..., the appearance of these studies was spontaneous because the topics of the conferences did not focus on Japanese literature. The only notable one was a panel of 5 articles on Japanese literature at the conference entitled "Japan in the world of East Asia and Southeast Asia". In the period of 2006 - 2018, a number of international and national conferences were organized. Of which, the conference entitled "The World of Haruki Murakami and Banana Yoshimoto" held on March 17, 2007 by the Embassy of Japan in Vietnam, The Vietnam - Japan Center for Human Resources Cooperation and Nhã Nam Culture and Media Joint-Stock Company was the first one. Since then, there have been 4 more conferences on Japanese literature organized, including 3 major conferences organized by the Faculty of Literature and Linguistics, University of Social Sciences and Humanities, Vietnam National University Hochiminh City. With a clear and focused topic, these conferences have attracted a great deal of in-depth studies on Japanese literature : 
Table 11. Conferences on Japan literature held in Vietnam (2006 - 2018)

\begin{tabular}{|c|c|c|}
\hline Title of the conference & Organizing institution & $\begin{array}{l}\text { Number of articles } \\
\text { on Japanese } \\
\text { literature }\end{array}$ \\
\hline $\begin{array}{l}\text { Thế giói của Haruki Murakami và Banana } \\
\text { Yoshimoto (The World of Haruki Murakami and } \\
\text { Banana Yoshimoto) }\end{array}$ & $\begin{array}{l}\text { The Vietnam - Japan Center } \\
\text { for Human Resources } \\
\text { Cooperation, } 2007\end{array}$ & 7 \\
\hline $\begin{array}{l}\text { Kawabata trong nhà truòng Việt Nam (Kawabata } \\
\text { in Vietnamese School) }\end{array}$ & $\begin{array}{l}\text { Hanoi National University } \\
\text { of Education, } 2009\end{array}$ & 5 \\
\hline $\begin{array}{l}\text { Quá trình hiện đại hoá văn học Nhật Bản và các } \\
\text { nuớc khu vục văn hoá chũ Hán (Modernization } \\
\text { process in Japanese literature and in the literatures } \\
\text { of East - Asian region (Vietnam, China, Korea)) }\end{array}$ & $\begin{array}{l}\text { Vietnam National University } \\
\text { Hochiminh City, } 2010\end{array}$ & 8 \\
\hline $\begin{array}{l}\text { Văn học Việt Nam và Nhật Bản trong bối cảnh } \\
\text { Đông Á (Vietnamese and Japanese Literature } \\
\text { Viewed from an East Asian Perspective) }\end{array}$ & $\begin{array}{l}\text { Vietnam National University } \\
\text { Hochiminh City, } 2011\end{array}$ & 20 \\
\hline $\begin{array}{l}\text { Nghiên cúu văn học Việt Nam và Nhật Bản trong } \\
\text { bối cảnh toàn cầu hoá thế kỷ XXI (Vietnamese } \\
\text { and Japanese literature in the globalization context) }\end{array}$ & $\begin{array}{l}\text { Vietnam National University } \\
\text { Hochiminh City, } 2013\end{array}$ & 27 \\
\hline
\end{tabular}

From the figures in the table above, it can be seen that the number of articles on Japanese literature increases with time, which reflects the increasing interest of Vietnamese scholars in this field. It is noteworthy that the conferences organized by Vietnam National University Hochiminh City always emphasized the relationship between Japanese and Vietnamese literature and placed them in the context of East Asia and the world throughout history, from ancient times (2011 conference) to modern times (2010 conference) and contemporary times (2013 conference).

\subsubsection{The diversification in literary genres and topics of the researches}

3.3.2.1 The studies of Japanese literature in the period of 2006 - 2018 not only continues to go into the literary genres which was studied in the previous period (poetry, short stories, novels) but also starts to discover new genres as essay and manga.

a. Essay is not a new genre in Japanese literature that has appeared since ancient times with Sei Shonagon's Makura no Soshi. However, due to the fact that this genre is not an outstanding one in comparison with other genres in Japanese literature, especially contemporary literature with well-known novelists as Murakami Haruki. On the other hand, also derived from the position as above, Japanese essays are almost not translated and introduced in Vietnam. Therefore, studies of Japanese 
essays in Vietnam are still limited. Ngô Trà My's thesis entitled Sei Shonagon's Makura no Soshi in the genre of Japanese essay $(2011)^{39}$ and articles entitled "Okashi sense in Sei Shonagon's Makura no Soshi" (2011) ${ }^{40}$ are the first studies of this genre in Vietnam. It should be noted that Ngô Trà My's choice to study Makura no Soshi is due to her perception of the importance of this work in the history of Japanese essay; therefore, she decided to translate the original work into Vietnamese for research, instead of selecting subject from Vietnamese translations. So far, only a total of 5 studies of Japanese essays (4 articles, 1 thesis) which focused on the first essay collection in Japanese literary history - Makura no Soshi of Sei Shonagon have been published in Vietnam.

b. In Japan, although appeared much later than folklore, poetry, short stories, novels, playscripts and essays, manga has quickly grown. The great number of printed copies of manga which surpasses other genres has expressed the widespread reception of this literary genre in the country. In Vietnam, manga has also been translated and published since the early 1990s, but not until 2002 did the first research article on Japanese manga entitled "Japanese manga and children's entertainment needs nowadays" (Đàm Thuỳ Dương) ${ }^{41}$ be published. So far, only 14 works (10 articles and 4 theses) have been researched on this genre. It is noteworthy that these studies mainly introduced manga's history (for example : "Introduction to Japanese manga"42, Japanese historical manga: Origin, value and experiences $^{43}$ ) or the reception of manga in Vietnam (for example: "Manga and its influence to Japanese and Vietnamese children" ${ }^{44}$; The influence of Japanese manga to pupils in Hanoi ${ }^{45}$; "Youth culture in Vietnam : A survey on manga in Hanoi" ${ }^{46}$ ), instead of studying specific works.

39 Ngô Trà My, Makura no Soshi (Chẩm thảo tử) của Sei Shonagon trong thể loại tuỳ bút cổ điển Nhật Bản, Luận văn thạc sĩ, Thành phố Hồ Chí Minh : Trường Đại học Khoa học Xã hội và Nhân văn, 2011.

40 Ngô Trà My, Cảm thức Okashi trong Chẩm thảo tử của Sei Shonagon, Niên giám binh luận văn học, Thành phố Hồ Chí Minh : NXB Đại học Sài Gòn, 2011.

41 Đàm Thuỳ Dương, Truyện tranh Nhật Bản và nhu cầu giải trí của trẻ em hiện nay, Diễn đàn Văn nghệ Viêt Nam, Số 2, 2002.

42 Hạ Thị Lan Phi, Vài nét về manga Nhật Bản, Nghiên cứu Đông Bắc Á, Số 6, 2004, pp.32-41.

43 Tống Thị Thanh Duyên, Truyện tranh lịch sử Nhật Bản : Nguồn gốc, giá trị và những bài học kinh nghiệm, Luận văn thạc sĩ, Thành phố Hồ Chí Minh : Trường Đại học Khoa học Xã hội và Nhân văn, 2015.

44 Lưu Thị Thu Thuỷ, Manga và sự ảnh hưởng của nó đối với thiếu nhi Nhật Bản và Việt Nam, Nghiên cứu Đông Bắc Á, Số 1.=, 2007.

45 Hạ Thị Lan Phi, Ảnh hưởng của manga Nhật Bản đến học sinh phổ thông tại thành phố Hà Nội, Luận án tiến sĩ, Hà Nội : Đại học Văn hoá Hà Nội, 2017.

46 Phạm Hoàng Hưng, Văn hóa giới trẻ tại Việt Nam qua một số kết quả khảo sát Manga tại Hà Nội, Bài giảng chuyên đề nghiên cứu Nhật Bản : Nhật Bản và châu A, Hà Nội : NXB Thế giới, 2012. 
The lack of in-depth studies of manga in Vietnam can be explained by Vietnamese's fixed idea of manga. For the majority of ordinary people, manga are considered entertainment products for children or teenagers, not authentic literary works. Affected by this concept, researchers also do not consider manga as a serious research subject and go into this field. Therefore, although there have been hundreds of manga translated and published in Vietnam, the number of copies sold is also superior to other genres, the study of manga in Vietnam is still limited and impossible to become an independent academic field. Even in universities, while some foreign universities have made manga studies become a regular subject in the bachelor program of Japanese Language and Culture (Stockholm University) ${ }^{47}$ or launched a master's and doctoral program in Manga Studies (Kyoto Seika University $)^{48}$, this literary genre is briefly introduced in the subject of Japanese youth culture in the bachelor program of Oriental Studies (Vietnam National University Hanoi). At this level, students are not sufficiently provided with knowledge and skills to undertake in-depth studies.

3.3.2.2 Research on Japanese traditional literary genres (short stories - novels, poetry, folklore) continues to develop. It is expressed by not only the increasing number of studies but also the in-depth diversification of research topics and subjects.

\section{a. Poetry}

The number of studies in Japanese poetry has increased from 2 in the period of $1976-1990$ to 23 in the period of $1991-2005$ and 70 in the period of $2006-2018$.

Chart 1. Number of studies in Japanese poetry in Vietnam (1976 - 2018)

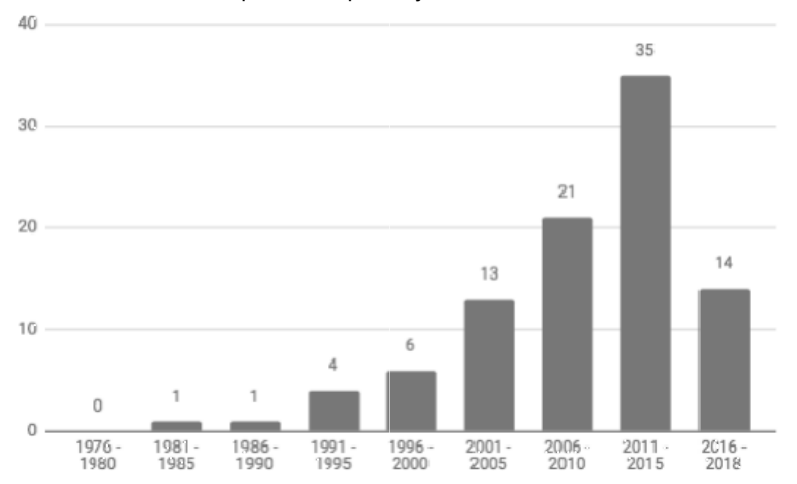

47 https://www.su.se/polopoly_fs/1.338943.1498731348!/menu/standard/file/JKA918\%20Manga\%20Studies\%2C\%2 Ocourse\%20description.pdf

48 http://www.kyoto-seika.ac.jp/eng/edu/graduate/manga/ 
Regarding the poetic form studied, in the period of 1991-2005, the studies of Japanese poetry in Vietnam consisted only of haiku and waka, of which studies of haiku dominated with 7 publications in comparison with 2 studies of waka). On contrary, in the period of 2006 - 2018, more Japanese poetic forms were studied, such as shintaishi (7 publications), $c i$ (詞, 2 publications), senryu (1 publication) and kanshi (1 publication) while haiku continues to be the most important poetic form studied in Vietnam.

Chart 2. Japanese poetry studies in Vietnam by poetic form studied (1991 - 2018)

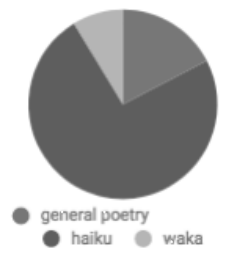

$1991-2005$

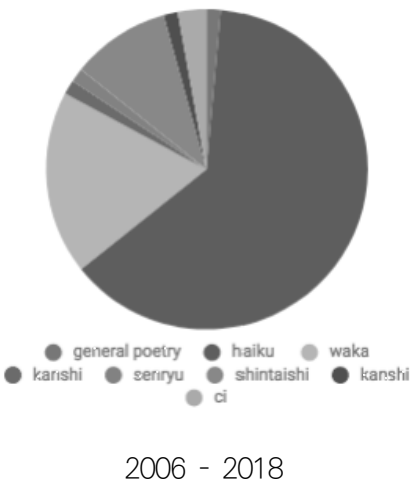

In spite of the above diversity, the study of Japanese poetry in Vietnam is not very appropriate when comparing the meaning of each poetic form in Japanese poetry history (waka has a long-lasting history from ancient times with valuable poetry collections such as Manyoshu, Kokinshu, Shin Kokinshu...; shintaishi marked the important change of Japanese poetry in the context of literary modernization of East Asian countries in the early 20th century). The focus of haiku in Vietnam can be explained by the reception of Japanese poetry in the country in particular and in the world in general. In particular, haiku was born late (the 17th century) but quickly developed and gradually took over the dominant position in Japanese poetry due to its short characteristic. The prevalence of haiku had attracted the attention of Westerners and created a haiku movement in the West with representatives like Ezra Pound and Amy Lowell. Similarly, in Vietnam, haiku was introduced after shintaishi but was quickly attracted the attention of the public. The reception of haiku in the country even promoted the formation of Vietnamese haiku. This fact greatly influenced the trend of poetry research focusing on haiku in Vietnam.

Regarding the the author/works studied, the period of 2006-2018 witnessed the 
appearance of a series of newly-introduced authors and works from ancient to contemporary times, compared with the number 2 works (Manyoshu, Kokinshu) and 1 author (Matsuo Basho) of the 1991 - 2005 period. Here are some examples :

Table 12. Some authors and works of Japanese poetry studied in Vietnam (2006 - 2018)

\begin{tabular}{|c|c|c|c|}
\hline Author/Work & Period & Poetic form & Related publication \\
\hline Masaoka Shiki & Modern & shintaishi & $\begin{array}{l}\text { "Masaoka Shiki and modern haiku" (Nguyễn Vũ Quỳnh } \\
\text { Nhu, 2010) }\end{array}$ \\
\hline $\begin{array}{l}\text { Nakahara } \\
\text { Chuya }\end{array}$ & Modern & shintaishi & $\begin{array}{l}\text { "Nakahara Chuya and distant inspiration" (Hoàng Long, } \\
\text { 2014) } 50\end{array}$ \\
\hline Saigyo Hoshi & Ancient & kanshi & $\begin{array}{l}\text { "Buddhist aesthetics of Saigyo Hoshi" (Nguyễn Lương } \\
\text { Hải Khôi, 2016) }\end{array}$ \\
\hline Yosa Buson & Ancient & Haiku & "Buson’s haiku" (Lê Nguyên Cẩn, 2007) \\
\hline Kobayashi Issa & Ancient & Haiku & $\begin{array}{l}\text { Inspiration of human livehood in Kobayashi Issa's haiku } \\
\text { (Nguyễn Thị Đào, 2017) }\end{array}$ \\
\hline $\begin{array}{l}\text { Ishikawa } \\
\text { Takuboku }\end{array}$ & Modern & shintaishi & $\begin{array}{l}\text { "Ishikawa Takuboku }(1886 \text { - 1912) : A drifting life" } \\
\text { (Nguyễn Nam Trân, 2012) }\end{array}$ \\
\hline Hyakunin Isshu & Ancient & Waka & $\begin{array}{l}\text { "About female poets in Hyakunin Isshu" (Trần Thị } \\
\text { Chung Toàn, 2012) }\end{array}$ \\
\hline Ikkyu & Ancient & kanshi & $\begin{array}{l}\text { "Chinese, Japanese and Korean writings on simple life } \\
\text { in a hut (a typological comparison)" (Phan Thị Thu } \\
\text { Hiền, 2014) }\end{array}$ \\
\hline
\end{tabular}

In general, Matsuo Basho is still the poet who received the most attention of Vietnamese researchers in literary studies with a total of 20 related publications (1991 - 2005: 7 publications; 2006 - $2018: 11$ publications). Furthermore, even in the general studies in Japanese poetry which do not go into specific authors or works, the mostly quoted poems are the works of Matsuo Basho. This situation can

49 Nguyễn Vũ Quỳnh Như, Masaoka Shiki và haiku cận đại, Nghiên cứu Văn học, Số 7, 2010, pp.131-141.

50 Hoàng Long, Nakahara Chuya và cảm hứng cao viễn, Bông hồng cho ngày tháng không tên, Hà Nội : NXB Văn học, 2014, pp.35-42.

51 Nguyễn Lương Hải Khôi, Mỹ học Phật giáo của Saigyo Hoshi, Nghiên cứu Văn học, Số 9, 2016, pp.95-105.

52 Lê Nguyên Cẩn, Thơ haiku của Buson, Văn học và Tuổi trẻ, Số 10, 2007, pp.30-32.

53 Nguyễn Thị Đào, Cảm hứng nhân tinh trong thơ haiku của Kobayashi Issa, Luận văn thạc sĩ. Hà Nội : Đại học Sư phạm Hà Nội, 2017.

54 Nguyễn Nam Trân, Ishikawa Takuboku (1886 - 1912) đời thơ lưu lạc, Văn học Việt Nam và Nhật Bản trong bối cảnh Đông Á, Thành phố Hồ Chí Minh : NXB Văn hoá - Văn nghệ, 2012, pp.598-615.

55 Trần Thị Chung Toàn, Về các nữ thi sĩ trong tuyển tập Hyakunin Isshu, Văn học Việt Nam và Nhật Bản trong bối cảnh Đông Á, Thành phố Hồ Chí Minh : NXB Văn hoá - Văn nghệ, 2012, pp.220-245.

56 Phan Thị Thu Hiền, Những mái lều ẩn cư trong văn chương Đông A : Nghiên cứu so sánh Trung Quốc Nhật Bản - Korea, Nghiên cứu Văn học, Số 1, 2014. 
be explained that Basho is the most famous haiku poet and a lot of his poems have been translated into Vietnamese ${ }^{57}$. In the context that not all of Vietnamese literary researchers are proficient in Japanese and the language of Japanese poetry, especially classical poetry, is relatively confusing to most ordinary Japanese learners, using the translation for research has become a mainstream trend and greatly influenced the choice of subject and scope of the researchers.

\section{b. Folklore}

The study of Japanese folklore in Vietnam in the period of 2006 - 2018 recorded an increase in the number of researches to 25 publications (compared with 10 publications in the 1991 - 2005 period). Besides, while there are only research articles in the previous period, the publications in this period consist of 3 theses and 1 monograph.

Regarding the subgenre studied, Japanese folklore studies in this period has also witnessed a certain degree of diversification. Specifically, in addition to the researches of Japanese fairy tales and legends, there are some studies on myths and funny stories. However, in general, fairy tales have always been of interest when accounting for $83 \%$ of total Japanese folklore studies (29 publications).

Table 13. Japanese folklore studies in Vietnam by subgenre studied (1991 - 2018)

\begin{tabular}{|c|c|c|c|}
\hline \multicolumn{2}{|c|}{$1991-2005$} & \multicolumn{2}{c|}{$2006-2018$} \\
\hline Subgenre & Number of publications & Subgenre & Number of publications \\
\hline Fairy tales & 9 & Fairy tales & 20 \\
\hline Legends & 1 & Myths & 3 \\
\hline & & Funny stories & 2 \\
\hline
\end{tabular}

In terms of the research problem, the most important characteristic of Japanese folklore studies in Vietnam is that the authors often put fairy tales, myths, legends of Japan in the comparison with the corresponding genres of other East Asian countries (China, Korea and mainly Vietnam) to find their similarities and differences in terms of both content and form aspects, then explained them by the cultural characteristics of each country. As my statistics, $70 \%$ of the studies use this approach. It can be seen that the diversification in this type of study is that researchers not only compared fairy tales of Japan and Vietnam, but also put some

57 Basho's Oku no Hosomichi has at least 3 Vietnamese translations by Vĩnh Sính, Nguyễn Nam Trân and Phùng Hoài Ngọc. 
specific works in the comparison, such as Nihon Ryoiki of Japan and Linh Nam chích quái (嶺南摭怪Selection of Strange Tales in Lĩnh Nam) or Thiền Uyển tập anh (禪苑集英Collection of Outstanding Figures of the Zen Garden) of Vietnam.

\section{c. Novels and short stories}

* Research on Japanese novels and short stories in the period of 2006 - 2018 marked the strong growth in quantity when the number of publications increased 5.7 times compared with the period of 1991 - 2005 (from 39 to 222), therefore maintains its dominance in the field of Japanese literary studies in Vietnam.

Chart 3. Number of studies in Japanese novels and short stories in Vietnam (1976 - 2018)

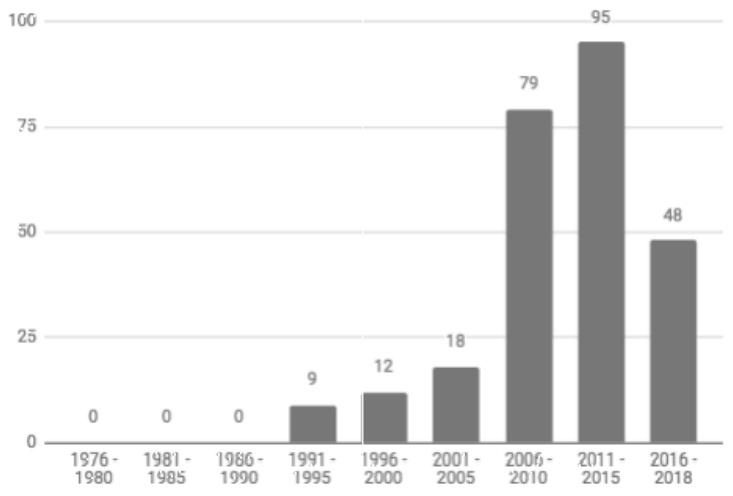

About the superiority of the studies of novels and short stories in Japanese literary studies in Vietnam in general and the strong growth of this field in the period of 2006 - 2018 in particular, it can be explained by the easy reception of the genre of novel and short stories, the large number of original works in general and Vietnamese translations in particular for researchers to study. In the context that those who are good at Japanese in Vietnam do not have a passion for studying literature and becoming professional researchers while faculties of literature in universities, the main institutions of training researchers in Japanese literature, mainly teaches English under the Ministry of Education's general program (students who want to study Japanese must study by themselves or study at Japanese centers outside), the situation that the study of Japanese literature is mainly based on Vietnamese, English or French translations is unavoidable. Therefore, the study on Japanese novels and short stories is conducted most because there are a lot of works of these genres translated into Vietnamese, especially in the period of 2006 - 2018. 
In terms of research subjects, it can be seen that studies on Japanese novels and short stories in Vietnam in the 2006 - 2018 period also followed the trend of diversification mentioned above. Specifically, while researchers only studied 2 authors in the 1954 - 1975 period (Takakura Teruo and Kawabata Yasunari) and 12 authors (4 authors in ancient times and 8 authors in modern times) in the 1991 2005 period, the number of author studied in this period increased to 25, including 3 authors in ancient times, 17 authors in modern times and 5 authors in contemporary times. The detailed information is expressed in the table below:

Table 14. Japanese prose writers studied in Vietnam by period ${ }^{58}$

\begin{tabular}{|c|c|c|c|}
\hline Period of authors & Ancient times & Modern times & $\begin{array}{c}\text { Contemporary } \\
\text { times }\end{array}$ \\
\hline $1991-2005$ & $\begin{array}{c}\text { Asai Ryoi } \\
\text { Ihara Saikaku } \\
\text { Murasaki Shikibu } \\
\text { Ueda Akinari }\end{array}$ & $\begin{array}{c}\text { Kawabata Yasunari } \\
\text { Kenzaburo Oe } \\
\text { Miyazawa Kenji } \\
\text { Natsume Soseki } \\
\text { Shimazaki Toson } \\
\text { Tetsuo Miura } \\
\text { Tokai Sanshi } \\
\text { Watanabe Junichi }\end{array}$ & \\
\hline $2006-2018$ & $\begin{array}{c}\text { Kyokutei Bakin } \\
\text { Murasaki Shikibu } \\
\text { Ueda Akinari }\end{array}$ & $\begin{array}{c}\text { Akutagawa Ryunosuke } \\
\text { Dazai Osamu } \\
\text { Futatabei Shimei } \\
\text { Hisaye Yamamoto } \\
\text { Inoue Yasushi } \\
\text { Kawabata Yasunari } \\
\text { Kenzaburo Oe } \\
\text { Komatsu Kiyoshi } \\
\text { Mishima Yukio } \\
\text { Natsume Soseki } \\
\text { Shiba Ryotaro } \\
\text { Shimazaki Toson } \\
\text { Shiroyama Saburo } \\
\text { Tanizaki Junichiro } \\
\text { Tetsuko Kuroyanagi } \\
\text { Tokai Sanshi }\end{array}$ & $\begin{array}{c}\text { Banana Yoshimoto } \\
\text { Haruki Murakami } \\
\text { Hitoni Nakano } \\
\text { Kazumi Yumoto } \\
\text { Yoko Tawada }\end{array}$ \\
\hline
\end{tabular}

It is noted that the level of interest of researchers to each author is not the same. This situation is clearly shown in the following table :

58 Writers studied by Vietnamese scholars for the first time appear in bold. 
Table 15. Research on specific authors by number of related publications in Vietnam

\begin{tabular}{|l|c|}
\hline Author & $\begin{array}{c}\text { Number of related } \\
\text { publications }\end{array}$ \\
\hline Kawabata Yasunari & 82 \\
\hline Haruki Murakami & 74 \\
\hline Kenzaburo Oe & 15 \\
\hline Murasaki Shikibu & 12 \\
\hline Akutagawa Ryunosuke & 11 \\
\hline Abe Kobo & 9 \\
\hline Banana Yoshimoto & 5 \\
\hline Tokai Sanshi, Ueda Akinari & 4 \\
\hline Dazai Osamu Shimazaki, Toson Natsume Soseki & 3 \\
\hline Kyokutei Bakin, Mishima Yukio, Tetsuko Kuroyanagi, Inoue Yasushi & 2 \\
\hline $\begin{array}{l}\text { Asai Ryoi, Ihara Saikaku, Miyazawa Kenji, Tetsuo Miura, Watanabe } \\
\text { Junichi, Futatabei Shimei, Hisaye Yamamoto }\end{array}$ & 1 \\
\hline
\end{tabular}

It can be easily seen that Kawabata Yasunari and Haruki Murakami have received much attention of Vietnamese scholars when studies on the two authors and their works account for $58 \%$ of the total number of studies on Japanese novels and short stories in Vietnam. This situation can be explained as follow:

- In the case of Kawabata Yasunari, the interest of Vietnamese scholars in his works can be explained by his reputation, the large number of works translated into Vietnamese and Japanese characteristics in Kawabata's works. First of all, it can not be ignored that Kawabata won the Nobel Prize in 1968. At that moment, the reputation of the award immediately aroused the translation and study of Kawabata Yasunari's works in South Vietnam, where there were a lot of advantageous conditions for approaching the literature of the world and readers had more open minds in comparison with readers in North Vietnam who only received proletarian literature. Specifically, in terms of translation, 5 of Kawabata's works were translated and published in Saigon in 1969, while in terms of research, the Journal of Literature also published 4 articles on Kawabata. For a long time, although the studies of Japanese literature in Vietnam did not improve, Kawabata's work continued to be translated into Vietnamese. This created a great premise for the development of the studies on Kawabata's works in the later. In addition, the undeniable identity of Japan in Kawabata's works has prompted Vietnamese scholars to study thoroughly Japanese cultural meaning contained in them, a way of approaching Japanese culture in the cultural integration context of Vietnam in 
Renovation Period.

- The reception of Vietnamese readers and researchers in the case of Haruki Murakami has a certain time gap. In 1996, the first translation of Noruwei no Mori (ノルウェイの森Norwegian Wood) by Hạnh Liên and Hải Thanh under the title of Rùng $\mathrm{Na}$ Uy was released. However, it did not attract the attention of the readers due to being considered as a sex book, even many sections whose content was not appropriate to Vietnamese culture were cut. After 10 years, when the Vietnamese society was more open and a new active readership of young readers was born, the second translation of Noruwei no Mori by Trịnh Lữ was well received. Thanks to this success, Nhã Nam Publishing Company has continuously translated and published Murakami's works, making him the most famous writer of Japan in Vietnam. It is noteworthy that, unlike the Japanese traditional meaning in Kawabata's works, what make Murakami attractive to readers in Vietnam as well as in other countries around the world are the easy-to-understand style and the content which is close to young readers. Furthermore, the "Murakami phenomenon" began to attract the attention of many researchers including both senior and young ones. Someone studied Murakami due to the love of his works while the others would like to explain a prominent phenomenon in Japanese contemporary literature. All have created a wave of studies on Murakami.

Generally, in the period of 2006 - 2018, although the trend of diversifying research subjects in the study of Japanese novels and short stories has continued, it can not be denied that the inadequacy of focusing too much on a small number of authors is relatively clear. Of course, it is impossible to expect that all authors will receive an equal interest because the influence and position of each writer in the literary history is not the same. However, the overemphasis on one or two authors will not provide accurate insights of Japanese literature in general and the genres of novel and short story in particular due to the fact that despite their reputation, Kawabata and Murakami can not represent the whole of Japanese literature. It should be noted that in the field of research, Vietnamese scholars need to be aware of their task to find and solve new problems, rather than follow trends and temporarily tastes.

* By comparing studies on Japanese novels and short stories between the two period of 1991 - 2005 and 2006 - 2018 in terms of research issues, it is found that their most obvious difference is that most publications in the 2006 - 2018 period 
had specific research issues and used approaches and methodologies to study the works, while $36 \%$ of the publications in the period of 1991 - 2005 did not use any specific approaches and methods but only introduced the authors and their works, for example : "Kenzaburo Oe won the Nobel Prize in Literature" (Bích Phương, 1994) ${ }^{59}$; "Miyazawa Kenji (1896 - 1933) : A famous author of children's literature of Japan" (Nguyễn Đỗ An Nhiên, 2000) ${ }^{60}$, "Natsume Soseki : Life and work" (Nguyễn Tuấn Khanh, 2005) ${ }^{61}$... Besides, the research scope has been narrowed to some specific works, rather than spreading out a number of works of a writer to conduct in-depth studies, for example: The proportion of studies on Kawabata Yasunari's works which clearly defined the scope of 1-3 specific works increased from $18 \%(1991-2005)$ to $37 \%$ (2006 - 2018). At the same time, the depth of the studies is also expressed in the fact that researchers tended to focus on one aspect of research subject and studied it thoroughly from different perspectives, instead of greedily dealing with all aspects of the subject. On the other hand, there are more and more comparative literature studies. It is noteworthy that the subjects used to compare with Japan are not only Vietnam but also other countries, such as China, Korea, France, India, Germany, the United States... This promises to bring new perception of Japanese literature and cultural meaning in Japanese literary works.

\section{d. Play scripts}

In comparison with the period of 1991-2005, the study of Japanese play scripts in Vietnam has almost no significant change in quantity (from 2 to 3 publications). In relation to other genres, this is the least interested one, even though the Vietnamese have known the existence of Noh and Kabuki for a long time. In my opinion, the limitations on accessing to Japanese traditional theater and translating Japanese play script translation have prevented the development of this field. However, a positive point is that in the period of 2006 - 2018, scholars have shifted from general introduction to studies on specific play scripts, such as Sotoba Komachi (Kan’ami), Sekidera Komachi (Zeami) and Akaoni (Hideki Noda).

\footnotetext{
59 Bích Phương, Kenzaburo Oe đạt giải Nobel văn chương, Kiến thức ngày nay, Số 154, 1994.

60 Nguyễn Đỗ An Nhiên, Miyazawa Kenji : Nhà văn đồng thoại nổi tiếng của Nhật Bản, Nhật Bản trong thế giới Đông Á và Đông Nam A, Thành phố Hồ Chí Minh : NXB Tổng hợp Thành phố Hồ Chí Minh, 2000.

61 Nguyễn Tuấn Khanh, Natsume Soseki : Con người và tác phẩm, Nghiên cứu Đông Băc Á, Số 6, 2005, pp.35-47.
} 


\subsubsection{The important role of donor agencies in promoting Japanese literary}

research in Vietnam

Just like translation activities, Japanese literary research activities in Vietnam during the period of 2006 - 2018 also received the support of Japanese donor agencies, namely the Japan Foundation. Since its establishment in 2008, the Japan Foundation Center for Cultural Exchange in Vietnam has been actively supporting Japanese literary research in the following three directions :

* Granting research institutions financial support for organizing conferences on Japanese literary studies : As mentioned above, during the period of 1991 - 2005, there were not any conferences on Japanese literary studies. In contrast, from 2006 to 2018,5 conferences on Japanese literature were held. Of these, three received funding from the Japan Foundation. Compared to other conferences, they are of a larger scale, attracting more scholars and attendees. Through these conferences, scholars had the opportunities not only to publish their latest studies of Japanese literature but also to exchange academic studies with prestigious Japanese researchers and build international academic network.

* Organizing the Japan Literary Research Contest: In 2016, the Japan Foundation Center for Cultural Exchange in Vietnam coordinated the Inoue Yasushi Memorial Foundation to hold the Inoue Yasushi Prize for Outstanding Research on Japanese Literature. This is the first contest for Japanese literary researchers in particular and foreign literary researchers in general in Vietnam whose aim is to promote the development of the field of Japanese literary studies in Vietnam. Up to now, the contest has been held three times and attracted a total of 52 researches of Vietnamese scholars who are living, studying and working in Vietnam and abroad. According to the judgment of the steering committee including 3 well-known researchers (Phan Nhật Chiêu - Vietnam National University Hochiminh City, Phan Hải Linh - Vietnam National University Hanoi, and Phạm Xuân Nguyên - Institute of Literature), most of the researches had chosen new issues and used modern approaches and methodologies to examine the research subject, and expressed the author's passion of Japanese literature. Among them, some outstanding studies were honored, such as : "Women's poetry in Manyoshu" (Nguyễn Anh Tuấn, First Prize in 2016) ${ }^{62}$, "Ethics without Borders: Translation and Palimpsests of Chugaku Rinrisho in East Asia at the beginning of the 20th century" (Nguyễn Nam, First 
Prize in 2017) $)^{63}$, "The life journey and memorial heritage of Inoue Yasushi's Dunhuang and Kazuo Ishiguro's Sleeping Giant” (Phan Thu Vân, First Prize in $2018)^{64}$.

* Supporting Vietnamese scholars to conduct researches on Japanese literature in Japan : Since 2006, the Japan Foundation has provided financial support to 7 young scholars of Vietnam to Japan for conducting researches. The detailed information is shown in the table below:

Table 16. Vietnamese scholars receiving the support of Japan Foundation Fellowship ${ }^{65}$

\begin{tabular}{|l|l|l|c|}
\hline \multicolumn{1}{|c|}{$\begin{array}{c}\text { Name of the } \\
\text { scholar }\end{array}$} & \multicolumn{1}{|c|}{ Institution } & \multicolumn{1}{|c|}{ Title of the research } & Year \\
\hline $\begin{array}{l}\text { Nguyen Vu } \\
\text { Quynh Nhu }\end{array}$ & $\begin{array}{l}\text { Vietnam National } \\
\text { University, Hochiminh } \\
\text { City }\end{array}$ & $\begin{array}{l}\text { A comparative research on the Japanese and } \\
\text { Vietnamese seasonal words towards the creation of the } \\
\text { Vietnamese Saijiki }\end{array}$ & 2017 \\
\hline $\begin{array}{l}\text { Ngo Vu Nhat } \\
\text { Phuong }\end{array}$ & Columbia University & $\begin{array}{l}\text { Lyric Poetry as Social Performance : Self-Expression } \\
\text { vs. Self-Construction in Classical Japanese Poetry }\end{array}$ & 2017 \\
\hline $\begin{array}{l}\text { Nguyen Luong } \\
\text { Hai Khoi }\end{array}$ & $\begin{array}{l}\text { University of Pedagogy, } \\
\text { Hochiminh City }\end{array}$ & $\begin{array}{l}\text { Buddhist Zen aesthetics in Kawabata Yasunari's works } \\
\text { - Point of view from his "Mirror world" }\end{array}$ & 2014 \\
\hline Ha Thi Lan Phi & $\begin{array}{l}\text { Vietnam Academy of } \\
\text { Social Sciences }\end{array}$ & $\begin{array}{l}\text { Study on Today's Japanese Youth's Lifestyle from } \\
\text { Behavior of comics Reading : Comparison to Viet Nam }\end{array}$ & 2013 \\
\hline $\begin{array}{l}\text { Nguyen Thi Lam } \\
\text { Anh }\end{array}$ & $\begin{array}{l}\text { Vietnam National } \\
\text { University, Hochiminh } \\
\text { City }\end{array}$ & $\begin{array}{l}\text { A comparative research on the influences of Buddhist } \\
\text { thinking on Shikibu Murasaki's Genji Monogatari and } \\
\text { Nguyen Du's Story of Thuy Kieu }\end{array}$ & 2012 \\
\hline $\begin{array}{l}\text { Le Thi Thanh } \\
\text { Tam }\end{array}$ & $\begin{array}{l}\text { Vietnam National } \\
\text { University, Hochiminh }\end{array}$ & $\begin{array}{l}\text { The Influence of Zen aesthetics on Japanese Haiku and } \\
\text { Vietnamese Classical Poetry }\end{array}$ & 2010 \\
\hline $\begin{array}{l}\text { Nguyen Luong } \\
\text { Hai Khoi }\end{array}$ & $\begin{array}{l}\text { University of Pedagogy, } \\
\text { Hochiminh City }\end{array}$ & $\begin{array}{l}\text { The Aesthetic Ideals of Kawabata Yasunari, in a } \\
\text { comparison with Aesthetic Ideals of Nguyen Tuan }\end{array}$ & 2008 \\
\hline Nguyen Thi Oanh & $\begin{array}{l}\text { Vietnamese Academy } \\
\text { of Social Sciences }\end{array}$ & $\begin{array}{l}\text { The Comparative Study of Folk Elements Contained in } \\
\text { Konjaku monogatari shu }\end{array}$ & 2005 \\
\hline Doan Le Giang & $\begin{array}{l}\text { Researching on Ueda Akinari's Romances. Comparing } \\
\text { to Records of Romances and Legends by Nguyen Du }\end{array}$ & 2003 \\
\hline
\end{tabular}

62 Original title: "Thơ ca của các nữ tác gia trong Manyoshu"

63 Original title: "Luân lý không biên giới : Phiên dịch và trùng tác Chigaku Rinrisho ở Đông A đầu thế kỉ XX"

64 Original title: "Hành trình cuộc đời và di sản ký ức trong tiểu thuyết Đôn Hoàng của Inoue Yasushi và tiểu thuyết Người khổng lồ ngủ quên của Kazuo Ishiguro"

65 https://www.jpf.go.jp/e/project/intel/study/fellowship/index.html 
These are meaningful supports because young scholars not only had the opportunity to gather documents and conduct their researches at Japan's universities, research institutes and public libraries, the rich source of documents which is not available in Vietnam, but also received the instruction and guidance of the leading professors in the field of Japanese literature.

In general, the study of Japanese literature in Vietnam in the period of 2006 2018 not only continues the trend of increasing in quantity but also has changes in content. This proves that the interest in Japanese literature of Vietnamese scholars has been transformed into an effort to discover and understand the soul of the Japanese people through an intermediate of literary works. Additionally, compared to the previous periods, this period also marked the emergence of professional activities such as conferences and research contests in the field of Japanese literature with the support of donor agencies.

\section{Conclusion}

For more than a century, Japanese translation and literary research activities in Vietnam have achieved certain achievements. Although there are differences in the evolution timeline, it can be seen that both of these fields have gone through three basic periods : the primitive period of more than half a century with a small number of translations and researches; the short period of establishing the foundation with the rapid increase in the number of translations and researches; the development period with the diversification of literary genres translated and studied, the transition from direct translation to direct translation in the field of translation and the deepening of content in the field of research. Especially, since 2006, both the fields of Japanese literary translation and research have dramatic changed. In the context of the globalization of the 21st century, it is believed that these fields will develop further, contributing positively to the mutual understanding and cultural exchange between Vietnam and Japan. 


\section{Bibliography}

Bách Thảo Sương tiên nữ (1942) Thơ Đường ở Nhật Bản, Tri Tân.

Bích Phương (1994) Kenzaburo Oe đạt giải Nobel văn chương, Kiến thức ngày nay, Số 154.

Đàm Thuỳ Dương (2002) Truyện tranh Nhật Bản và nhu cầu giải trí của trẻ em hiện nay, Diễn đàn Văn nghệ Viêt Nam, Số 2.

Đào Thị Thu Hằng (2007), Văn hoá Nhật Bản và Kawabata Yasunari, Hà Nội : NXB Giáo dục.

Hà Thanh Vân (2010) So sánh loại tiểu thuyết "tài tử giai nhân" ở một số nước phương Đông thơoi kỳ trung đại, Hà Nội : NXB Khoa học Xã hội.

Hạ Thị Lan Phi (2004) Vài nét về manga Nhật Bản, Nghiên cứu Đông Bắc A, Số 6, pp.32-41.

Hạ Thị Lan Phi (2017) Ảnh hưởng của manga Nhật Bản đến học sinh phổ thông tại thành phố Hà Nội, Luận án tiến sĩ, Hà Nội : Đại học Văn hoá Hà Nội.

Hàn Mặc Tử (1936) Thi văn Nhật Bản với phong trào Âu hoá, Sài Gòn.

Hoàng Long (2014) Nakahara Chuya và cảm hứng cao viễn, Bông hồng cho ngày tháng không tên, Hà Nội : NXB Văn học, pp.35-42.

Hữu Ngọc (1992) Dạo chơi vưởn văn Nhật Bản, Hà Nội : NXB Giáo dục.

Kawaguchi Kenichi (1998) Hai nàng Kiều Việt Nam và Nhật Bản, Kỷ yếu Hội thảo quốc tế Việt Nam học lần I, Hà Nội : NXB Đại học Quốc gia Hà Nội, pp.113-116.

Komatsu Kiyoshi (1945) Cuộc tái ngộ, Trung Bắc tân văn.

Komatsu Kiyoshi (2004) Bài bạt Kim Vân Kiều, Nghiên cứu Văn học Số 11, pp.55-61.

Lê Nguyên Cẩn (2007) Thơ haiku của Buson, Văn học và Tuổi trẻ, Số 10, pp.30-32.

Lưu Thị Thu Thuỷ (2007) Manga và sự ảnh hưởng của nó đối với thiếu nhi Nhật Bản và Việt Nam, Nghiên cứu Đông Bắc Á, Số 1.

Mai Chương Đức (1969) Tiểu thuyết Nhật Bản, Văn học (miền nam), Số 90.

Ngô Trà My (2011) Cảm thức Okashi trong Chẩm thảo tử của Sei Shonagon, Niên giám binh luận văn học, Thành phố Hồ Chí Minh : NXB Đại học Sài Gòn.

Ngô Trà My (2011) Makura no Soshi (Chẩm thảo tử) của Sei Shonagon trong thể loại tuỳ bút cổ điển Nhật Bản, Luận văn thạc sĩ, Thành phố Hồ Chí Minh : Trường Đại học Khoa học Xã hội và Nhân văn.

Nguyễn Bằng Giang (1969) Bài thơ con cóc bất hủ trong nền văn học Nhật, Văn học (miền nam), Số 90.

Nguyễn Đỗ An Nhiên (2000) Miyazawa Kenji : Nhà văn đồng thoại nổi tiếng của Nhật Bản, Nhật Bản trong thế giới Đông Á và Đông Nam Á, Thành phố Hồ Chí Minh : NXB Tổng hợp Thành phố Hồ Chí Minh.

Nguyễn Huy Thắng (2013) Truyện tranh ở Việt Nam - Thực trạng và triển vọng, Hội thảo nhân 40 năm quan hệ ngoại giao Việt Nam - Nhật Bản, Hà Nội.

Nguyễn Lương Hải Khôi (2016) Mỹ học Phật giáo của Saigyo Hoshi, Nghiên cứu Văn học, Số 9, pp.95-105. Nguyễn Năm (1964) Mây gió Hakone, tiểu thuyết của Takakura Teruo, Nghiên cứu Văn học, Số 2, pp.83-86.

Nguyễn Nam Trân (2012) Ishikawa Takuboku (1886 - 1912) đời thơ lưu lạc, Văn học Việt Nam và Nhật Bản trong bối cảnh Đông A, Thành phố Hồ Chí Minh : NXB Văn hoá - Văn nghệ, pp.598-615.

Nguyễn Thị Đào (2017) Cảm hứng nhân tinh trong thơ haiku của Kobayashi Issa, Luận văn thạc sĩ, Hà Nội : Đại học Sư phạm Hà Nội.

Nguyễn Thị Nguyệt (2010) Khảo sát và so sánh một số típ truyện và môtip truyện kể dân gian Việt Nam Nhật Bản, Hà Nội : NXB Đại học Quốc gia.

Nguyễn Thị Thanh Xuân (2008) Văn học Nhật Bản tại Việt Nam, Thành phố Hồ Chí Minh : NXB Đại học Quốc gia Thành phố Hồ Chí Minh.

Nguyễn Tuấn Khanh (1995) Matsuo Basho, nhà thơ lớn của thể thơ haiku, Nghiên cứu Nhật Bản, Số 3, pp. $48-51$. 
Nguyễn Tuấn Khanh (1998) Văn học Nhật Bản hiện đại từ thời Minh Trị đến nay, Văn học Nhật Bản, Hà Nội :

Viện Thông tin Khoa học Xã hội, pp.91-107.

Nguyễn Tuấn Khanh (2005) Natsume Soseki : Con người và tác phẩm, Nghiên cứu Đông Bắc Á, Số 6, pp.35-47.

Nguyễn Tuấn Khanh (2011) Những cây bút kiệt xuất trong văn học Nhật Bản hiện đại, Hà Nội : NXB Khoa học Xã hội.

Nguyễn Vũ Quỳnh Như (2010) Masaoka Shiki và haiku cận đại, Nghiên cứlu Văn học, Số 7, pp.131-141.

Nguyễn Vỹ (1982) Thu và thơ Nhật Bản, Phổ thông, Số 43.

Nhật Chiêu (1986) Tìm hiểu thơ haiku Nhật Bản, Sông Hương, Số 21.

Nhật Chiêu (1998) Văn học Nhật Bản tử khởi thuỷ đến 1868, Hà Nội : NXB Giáo dục.

Phạm Hoàng Hưng (2012) Văn hóa giới trẻ tại Việt Nam qua một số kết quả khảo sát Manga tại Hà Nội, Bài giảng chuyên đề nghiên cứu Nhật Bản : Nhật Bản và châu Á, Hà Nội : NXB Thế giới.

Phan Thị Thu Hiền (2014) Những mái lều ẩn cư trong văn chương Đông Á : Nghiên cứu so sánh Trung Quốc - Nhật Bản - Korea, Nghiên cứlu Văn học, Số 1.

R. M. Alberes, Roger Bastile, Rene Sieffert (1973) Văn học thế giới hiện đại, Bửu Ý dịch, Sài Gòn : NXB An Tiêm. Sei Kubota (1965) Tình hình văn học hiện đại Nhật Bản, Nghiên cứu Văn học, Số 6, pp.82-89.

Tatiana P. Grigorieva (1999) Thiền trong thơ Haiku Nhật Bản, Nghiên cứu Văn học, Số 4, pp.60-64.

Tống Thị Thanh Duyên (2015) Truyện tranh lịch sử Nhật Bản : Nguồn gốc, giá trị và những bài học kinh nghiệm, Luận văn thạc sĩ, Thành phố Hồ Chí Minh : Trường Đại học Khoa học Xã hội và Nhân văn.

Trần Hải Yến (1998) Giai nhân kỳ ngộ diễn ca trong dòng văn học duy tân yêu nước đầu thế kỷ XX, Luận án tiến sĩ, Hà Nội : Viện Văn học.

Trần Hải Yến (1999) Một số nét đặc trưng của văn học Nhật Bản, Nghiên cứu Nhật Bản, Số 4, pp.31-38. Trần Nghĩa (1993) Tiểu thuyết chữ Hán của Nhật Bản, Hán Nôm, Số 4.

Trần Thị Chung Toàn (2012) Về các nữ thi sĩ trong tuyển tập Hyakunin Isshu, Văn học Việt Nam và Nhật Bản trong bối cảnh Đông Á, Thành phố Hồ Chí Minh : NXB Văn hoá - Văn nghệ, pp.220-245.

Uyên Minh (1969) Yếu tố Eros trong truyền thống văn học Nhật Bản, Văn học (miền nam), Số 90.

Vĩnh Sính (2001) Về tác phẩm Giai nhân kỳ ngộ diễn ca: Nguồn gốc và ý nghĩa, Việt Nam và Nhật Bản : Giao lưu văn hoá, Vĩnh Sính, Thành phố Hồ Chí Minh : NXB Tổng hợp TPHCM, pp.465-469.

Graduate School of Manga. Master's Program. Kyoto Seika University. Access date : 2018.7.31. $\langle$ http://www.kyoto-seika.ac.jp/eng/edu/graduate/manga/〉

Department of Asian, Middle Eastern and Turkish Studies. Manga Studies, FC, 7.5hp, fall semester 2017. Stockholm universitet. Access date : 2018.7.31.

<https://www.su.se/polopoly_fs/1.338943.1498731348!/menu/standard/file/JKA918\%20Manga\%20Studies\%2 C\%20course\%20description.pdf $>$

Japanese Studies and Intellectual Exchange Department. Japanese Studies Fellowships. Japan Foundation. Access date : 2018.7.31. 〈https://www.jpf.go.jp/e/project/intel/study/fellowship/index.html〉

阮英俊 Anh Tuan NGUYEN

(ベトナム) ハノイ国家大学東洋学学部講師。日中比較文学、日本古典文学、女性文学。「日本で の弁財天信仰の形成、発展と現地化」(『宗教研究』1、2016)、『全唐詩』と『万葉集』における宮廷 女性の詩」(『人文と社会科学』4，2017)、「唐武宗の廃仏政策」(『宗教研究』7、2017)、「全唐詩』と 『万葉集』における女性の詩の中の四季」(『東北アジア研究』10、2017)、「『全唐詩』と『万葉集』にお ける女性の詩の研究の状況」(『社会科学情報』10、2017)、「唐代の妓女の詩のテーマの研究」(『中 国研究』3、2018)など。 